\title{
Synthesis and Polymorphism of Mixed Aluminum-Gallium Oxides
}

Daniel S. Cook, Joseph E. Hooper, Daniel M. Dawson, Janet M. Fisher, David Thompsett, Sharon E. Ashbrook,* and Richard I. Walton*

Cite This: https://dx.doi.org/10.1021/acs.inorgchem.9b03459

Read Online

ABSTRACT: The synthesis of a new solid solution of the oxyhydroxide $\mathrm{Ga}_{5-x} \mathrm{Al}_{x} \mathrm{O}_{7}(\mathrm{OH})$ is investigated via solvothermal reaction between gallium acetylacetonate and aluminum isopropoxide in 1,4-butanediol at $240{ }^{\circ} \mathrm{C}$. A limited compositional range of $0 \leq x \leq 1.5$ is produced, with the hexagonal unit cell parameters refined from powder X-ray diffraction (XRD) showing a linear contraction in unit cell volume with an increase in $\mathrm{Al}$ content. Solid-state ${ }^{27} \mathrm{Al}$ and ${ }^{71} \mathrm{Ga}$ nuclear magnetic resonance (NMR) spectroscopies show a strong preference for Ga to occupy the tetrahedral sites and $\mathrm{Al}$ to occupy the octahedral sites. Using isopropanol as the solvent, $\gamma-\mathrm{Ga}_{2-x} \mathrm{Al}_{x} \mathrm{O}_{3}$ defect spinel solid solutions with $x \leq 1.8$ can be prepared at $240{ }^{\circ} \mathrm{C}$ in $24 \mathrm{~h}$. These materials are nanocrystalline, as evidenced by their broad diffraction profiles; however, the refined cubic lattice parameter shows a linear relationship with the Ga:Al content, and

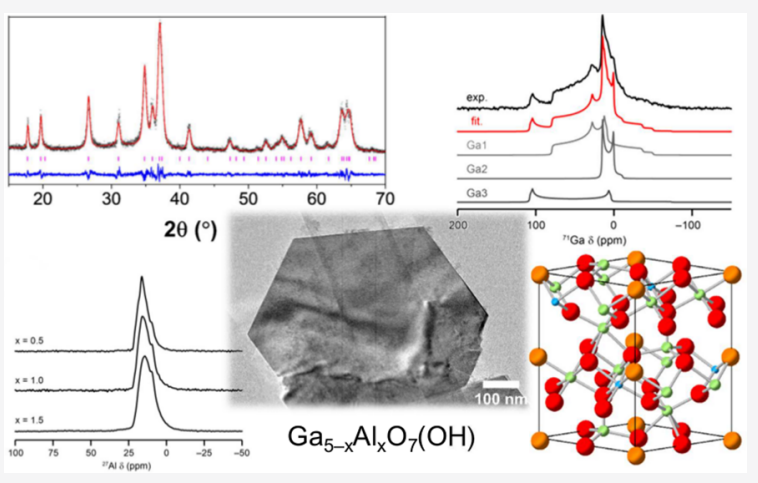
solid-state NMR spectroscopy again shows a preference for Al to occupy the octahedral sites. Thermal decomposition of $\mathrm{Ga}_{5-x} \mathrm{Al}_{x} \mathrm{O}_{7}(\mathrm{OH})$ occurs via poorly ordered materials that resemble $\varepsilon$ - $\mathrm{Ga}_{2-x} \mathrm{Al}_{x} \mathrm{O}_{3}$ and $\kappa-\mathrm{Ga}_{2-x} \mathrm{Al}_{x} \mathrm{O}_{3}$, but $\gamma$ - $\mathrm{Ga}_{2-x} \mathrm{Al}_{x} \mathrm{O}_{3}$ transforms above $750{ }^{\circ} \mathrm{C}$ to monoclinic $\beta-\mathrm{Ga}_{2-x} \mathrm{Al}_{x} \mathrm{O}_{3}$ for $0 \leq x \leq 1.3$ and to hexagonal $\alpha$ - $\mathrm{Ga}_{2-x} \mathrm{Al}_{x} \mathrm{O}_{3}$ for $x=1.8$, with intermediate compositions of $1.3<x<1.8$ giving mixtures of the $\alpha$ - and $\beta$-polymorphs. Solid-state NMR spectroscopy shows only the expected octahedral $\mathrm{Al}$ for $\alpha-\mathrm{Ga}_{2-x} \mathrm{Al}_{x} \mathrm{O}_{3}$, and for $\beta-\mathrm{Ga}_{2-x} \mathrm{Al}_{x} \mathrm{O}_{3}$, the $\sim 1: 2$ tetrahedral:octahedral $\mathrm{Al}$ ratio is in good agreement with the results of Rietveld analysis of the average structures against powder XRD data. Relative energies calculated by periodic density functional theory confirm that there is an $\sim 5.2 \mathrm{~kJ} \mathrm{~mol}^{-1}$ penalty for tetrahedral rather than octahedral $\mathrm{Al}$ in $\mathrm{Ga}_{5-x} \mathrm{Al}_{x} \mathrm{O}_{7}(\mathrm{OH})$, whereas this penalty is much smaller $\left(\sim 2.0 \mathrm{~kJ} \mathrm{~mol}{ }^{-1}\right)$ for $\beta-\mathrm{Ga}_{2-x} \mathrm{Al}_{x} \mathrm{O}_{3}$, in good qualitative agreement with the experimental NMR spectra.

\section{INTRODUCTION}

Polymorphism in the $\mathrm{Al}-\mathrm{O}, \mathrm{Al}-(\mathrm{OH})$, and $\mathrm{Al}-\mathrm{O}-(\mathrm{OH})$ systems is well-established and has been researched extensively, in part owing to the huge importance of aluminum oxide polymorphs as supports for precious metals and other reactive species in many areas of catalysis. ${ }^{1,2}$ Alumina polymorphs (in particular $\gamma-\mathrm{Al}_{2} \mathrm{O}_{3}$ ) are used not only as catalyst supports but also as adsorbents, coatings, soft abrasives, or catalysts themselves, owing to their typically large surface areas and high surface activity. ${ }^{3}$ At least 11 oxides, hydroxides, and oxyhydroxides of aluminum are known. ${ }^{1}$ The thermodynamically stable polymorph of alumina, at room temperature and pressure, is $\alpha-\mathrm{Al}_{2} \mathrm{O}_{3}$ (corundum), and all metastable aluminas, commonly termed transition aluminas in industry, convert to this polymorph at a sufficiently high temperature.

Gallium oxide polymorphism had received comparatively little attention until 5 years ago, when an interest in the electronic properties of various forms of the materials has attracted a growing amount of attention, ${ }^{4}$ in particular in microelectronics where the large band gap of $\beta-\mathrm{Ga}_{2} \mathrm{O}_{3}$ offers new possibilities in high-frequency power devices, ${ }^{5}$ but also in photocatalysis where mixtures of polymorphs can lead to cooperative behavior at phase junctions. ${ }^{6,7}$ Much of the previous understanding of the structures of gallium oxide polymorphs stemmed from the work of Roy and co-workers in the $1950 \mathrm{~s},{ }^{8,9}$ and until recently, the polymorphism in the Ga$\mathrm{O}, \mathrm{Ga}-(\mathrm{OH})$, and $\mathrm{Ga}-\mathrm{O}-(\mathrm{OH})$ systems remained poorly characterized despite a large number of publications on the structural characterization of gallium oxide. ${ }^{10-14}$ The recent work of some of us clarified the structures of a number of gallium oxide polymorphs, some of which contain inherent structural disorder leading to poor crystallinity. ${ }^{15,16}$ The thermodynamically stable polymorph under ambient conditions is the monoclinic $\beta$-polymorph (in contrast to the $\alpha$ polymorph for aluminum oxide) whose structure contains a 1:1 octahedral:tetrahedral cation ratio, both in distorted coordination geometry. ${ }^{17} \alpha-\mathrm{Ga}_{2} \mathrm{O}_{3}$, structurally analogous to $\alpha-\mathrm{Al}_{2} \mathrm{O}_{3}$, is metastable, but $\beta-\mathrm{Ga}_{2} \mathrm{O}_{3}$ irreversibly converts to this polymorph at high pressure because $\alpha-\mathrm{Ga}_{2} \mathrm{O}_{3}$ has a smaller molar volume. ${ }^{18}$ The cation-defective spinel $\gamma-\mathrm{Ga}_{2} \mathrm{O}_{3}$ can be

Received: November 26, 2019 
prepared directly by oxidation of gallium metal in an aminoalcohol. ${ }^{15,16,19} \gamma-\mathrm{Ga}_{2} \mathrm{O}_{3}$ is structurally analogous to $\gamma$ $\mathrm{Al}_{2} \mathrm{O}_{3}{ }^{20}$ both having disordered spinel structures containing small amounts of cations occupying nonspinel sites in the unit cell yet allowed in the $F d \overline{3} m$ space group. ${ }^{16}$ Other less wellcharacterized forms of $\mathrm{Ga}_{2} \mathrm{O}_{3}$ include the $\varepsilon$ - and $\kappa$-polymorphs, whose preparation is complicated by their transient nature during thermal decompositions of other gallium oxides or oxyhydroxides. $^{15}$

Given the present interest in the electronic properties of gallium oxides, it is timely to consider the polymorphism of solid solutions of gallium and aluminum oxides. As noted above, although the two binary oxide systems show similarities in the types of structures adopted, they show different relative stabilities and, in fact, are accessed by different synthesis approaches. The greater preference of tetrahedral coordination by gallium is of note, and this could lead to stabilization of the various polymorphs at different temperature ranges and may alter the properties, such as surface chemistry for catalysis, or the band gap for electronic applications. Roy and co-workers reported on the polymorphism in the $\mathrm{Ga}-\mathrm{Al}-\mathrm{O}$ system in the 1950 s at the same time as they performed their research with $\mathrm{Ga}_{2} \mathrm{O}_{3}$ polymorphism. ${ }^{21}$ von Wartenberg and Reusch had previously shown in 1932 that solid solutions of $\beta$ - $\mathrm{Ga}_{2-x} \mathrm{Al}_{x} \mathrm{O}_{3}$ could be prepared at high temperatures, one of the earliest papers detailing polymorphism in the $\mathrm{Ga}-\mathrm{Al}-\mathrm{O}$ system. ${ }^{22} \mathrm{~A}$ hexagonal phase with a composition of $\mathrm{GaAlO}_{3}$ was reported by Roy and co-workers, via hydrothermal routes, although its structure was not assigned. ${ }^{21}$ This material was later investigated by MacDonald et al., ${ }^{23}$ and several possible hexagonal space groups were suggested on the basis of systematic absences in powder X-ray diffraction (XRD) patterns, and other new ternary phases also reported. More recent work by Inoue and co-workers on the $\mathrm{Ga}-\mathrm{Al}-\mathrm{O}$ system used solvothermal synthesis to prepare $\gamma-\mathrm{Ga}_{2-x} \mathrm{Al}_{x} \mathrm{O}_{3}$ defect spinels. $^{24-28}$ These mixed-metal $\gamma-\mathrm{Ga}_{2-x} \mathrm{Al}_{x} \mathrm{O}_{3}$ spinels have been explored for some catalysis applications, including their use in the selective catalytic reduction (SCR) of NO by methane, ${ }^{25,27-31}$ dehydrogenation of propane, ${ }^{32,33}$ and dimethyl ether steam re-forming. ${ }^{34} \gamma-\mathrm{Ga}_{2} \mathrm{O}_{3}$ supported on $\gamma$ $\mathrm{Al}_{2} \mathrm{O}_{3}$ has been applied for photocatalysis. ${ }^{35}$

\section{EXPERIMENTAL SECTION}

Solvothermal synthesis of mixed aluminum-gallium oxides was investigated using temperatures lower than those applied previously by Inoue and co-workers ${ }^{24-28}$ using either 1,4-butanediol or isopropanol as a solvent. Solvothermal synthesis of the solid solution $\mathrm{Ga}_{5-x} \mathrm{Al}_{x} \mathrm{O}_{7}(\mathrm{OH})$ was achieved from $0.4 \mathrm{~g}(1.01 \mathrm{mmol})$ of $\mathrm{Ga}(\mathrm{acac})_{3}$ (Sigma, 99.99\%), where acac is acetylacetonate, and an appropriate amount of $\mathrm{Al}(\mathrm{acac})_{3}$ (Merck, $\geq 98 \%$ ), which were added to a $20 \mathrm{~mL}$ PTFE liner followed by the addition of $8 \mathrm{~mL}$ of 1,4-butanediol. The reaction mixture was stirred at room temperature for $10 \mathrm{~min}$ before being sealed inside a stainless-steel autoclave and placed inside a preheated fan-assisted oven at $240{ }^{\circ} \mathrm{C}$ for $96 \mathrm{~h}$. Then, the autoclave was allowed to cool naturally to ambient temperature, and the vessel opened to reveal a white powder, which was dispersed by magnetic stirring in the mother liquor followed by addition of acetone to reduce the viscosity of the diol. The material was then collected by suction filtration, washed with additional acetone, and dried overnight at 70 ${ }^{\circ} \mathrm{C}$. To form $\gamma-\left(\mathrm{Al}_{1-x} \mathrm{Ga}_{x}\right)_{2} \mathrm{O}_{3}, 0.4 \mathrm{~g}$ (1.01 mmol) of $\mathrm{Ga}(\mathrm{acac})_{3}$ (Aldrich, 99.99\%) and an appropriate amount of $\mathrm{Al}\left(\mathrm{O}^{i} \mathrm{Pr}\right)_{3}$ (Aldrich, $\geq 98 \%)$, to give a $(2-x): x$ Ga:Al molar ratio $(0 \leq x \leq 1.8)$, were added to a PTFE liner followed by the addition of $10 \mathrm{~mL}$ of isopropanol. The reaction mixture was stirred at room temperature for $5 \mathrm{~min}$ before being sealed inside a stainless-steel autoclave and placed inside a preheated fan-assisted oven at $240{ }^{\circ} \mathrm{C}$ for $24 \mathrm{~h}$. The autoclave was allowed to cool naturally to ambient temperature, and the white solid product was collected by suction filtration and then washed with copious amounts of acetone before being dried at $70{ }^{\circ} \mathrm{C}$ overnight. Thermal decomposition of the solvothermally prepared materials to $\beta$ - $\left(\mathrm{Al}_{1-x} \mathrm{Ga}_{x}\right)_{2} \mathrm{O}_{3}$ and $\alpha-\left(\mathrm{Al}_{1-x} \mathrm{Ga}_{x}\right)_{2} \mathrm{O}_{3}$ was guided by thermodiffractometry experiments (see below), and materials were then heated in air in muffle furnaces to $1400{ }^{\circ} \mathrm{C}$.

Powder XRD patterns were recorded at room temperature using a Panalytical X'Pert Pro MPD instrument operating with monochromatic $\mathrm{Cu} \mathrm{K} \alpha 1$ radiation and equipped with a PIXcel solid-state detector. Full pattern analysis of powder patterns was performed using the Pawley method within the TOPAS software to determine lattice parameters. ${ }^{36}$ A Bruker D8 Advance powder diffractometer operating with $\mathrm{Cu} \mathrm{K} \alpha 1 / 2$ radiation and equipped with a VÅNTEC-1 solid-state detector with an Anton Parr XRK900 chemical reaction chamber was used to collect powder XRD data with in situ heating. A typical data collection involved heating from 30 to 810 or $900{ }^{\circ} \mathrm{C}$ at a rate of 10 ${ }^{\circ} \mathrm{C} \mathrm{min}{ }^{-1}$ with $30{ }^{\circ} \mathrm{C}$ intervals holding for $300 \mathrm{~s}$ at each interval prior to data collection to allow the temperature to equilibrate.

Scanning electron microscopy (SEM) images were recorded using a ZEISS GEMINI instrument. A small amount of sample was placed on carbon tape prior to analysis. Transmission electron microscopy (TEM) was performed using a JEOL 2000FX instrument with samples placed on holey carbon copper grids via dispersion in acetone.

Thermogravimetric analysis (TGA) coupled with differential scanning calorimetry (DSC) was used to determine mass loss in samples upon heating from room temperature to usually $1000{ }^{\circ} \mathrm{C}$ using a Mettler Toledo TGA/DSC 1-600 instrument.

Solid-state ${ }^{1} \mathrm{H}$ nuclear magnetic resonance (NMR) spectra were recorded using a Bruker Avance III spectrometer equipped with a 14.1 $\mathrm{T}$ wide-bore superconducting magnet (Larmor frequency of 600.13 $\mathrm{MHz}$ ) and standard Bruker $1.3 \mathrm{~mm}$ magic angle spinning (MAS) probe (MAS rate of $55 \mathrm{kHz}$ ) at the University of St Andrews. ${ }^{1} \mathrm{H}$ MAS NMR spectra were recorded with signal averaging for 16 transients with a recycle interval of $60 \mathrm{~s}$. Chemical shifts are reported in parts per million relative to tetramethylsilane using L-alanine as a secondary solid reference $\left(\delta_{\mathrm{CH}_{3}}=20.5 \mathrm{ppm}\right)$.

Solid-state ${ }^{27} \mathrm{Al}$ NMR spectra were recorded using a Bruker Avance III spectrometer equipped with a $14.1 \mathrm{~T}$ wide-bore superconducting magnet (Larmor frequency of $156.4 \mathrm{MHz}$ ) and a standard Bruker 3.2 mm MAS probe (MAS rate of $20 \mathrm{kHz}$ ) at the University of St Andrews. ${ }^{27} \mathrm{Al}$ MAS NMR spectra were recorded with signal averaging for 1024-4096 transients with a recycle interval of $0.5 \mathrm{~s}$ for all materials apart except the $\beta-\mathrm{Ga}_{2-x} \mathrm{Al}_{x} \mathrm{O}_{3}$ series, for which a recycle interval of $3 \mathrm{~s}$ was used. An excitation pulse with an inherent flip angle of $\sim 4^{\circ}$ was used to enable accurate quantitation. ${ }^{1} \mathrm{H}-{ }^{27} \mathrm{Al}$ crosspolarization (CP) MAS NMR spectra were recorded with a spin-lock pulse (ramped for ${ }^{1} \mathrm{H}$ ) of $1 \mathrm{~ms}$, and high-power continuous wave decoupling of ${ }^{1} \mathrm{H}\left(\nu_{1} \approx 80 \mathrm{kHz}\right)$ was applied during acquisition. Signal averaging was carried out for 10240-20480 transients with a recycle interval of $3 \mathrm{s.}{ }^{27} \mathrm{Al}$ multiple-quantum (MQ) MAS NMR spectra were recorded using an amplitude-modulated z-filtered experiment. ${ }^{37}$ Signal averaging was carried out for $240-1008$ transients for each of up to $160 t_{1}$ increments of $25 \mu \mathrm{s}$ with a recycle interval of $0.5 \mathrm{~s}$. Spectra are shown after shearing and referencing according to Pike et al. ${ }^{38}$ Chemical shifts are reported in parts per million relative to $1.1 \mathrm{M} \mathrm{Al}\left(\mathrm{NO}_{3}\right)_{3}$ using $\mathrm{Al}(\mathrm{acac})_{3}$ as a secondary solid reference $\left(\delta_{\text {iso }}=0.0 \mathrm{ppm}\right)$.

Solid-state ${ }^{71} \mathrm{Ga}$ NMR spectra were recorded using either a Bruker Avance II or Bruker Avance NEO console equipped with a $20.0 \mathrm{~T}$ wide-bore superconducting magnet (Larmor frequency of 259.3 $\mathrm{MHz}$ ) and Bruker $1.3 \mathrm{~mm}$ double-broadband HXY probe (MAS rates of $50-55 \mathrm{kHz}$ ) or JEOL $1 \mathrm{~mm}$ double-resonance probe (MAS rate of $75 \mathrm{kHz}$ ) at the UK $850 \mathrm{MHz}$ solid-state NMR facility. ${ }^{71} \mathrm{Ga}$ MAS NMR spectra were recorded using a rotor-synchronized spin-echo pulse sequence with an echo delay of one rotor period (i.e., 13.3-20.0 $\mu \mathrm{s})$. Signal averaging was carried out for 3360-56000 transients with 
a recycle interval of $0.5-2 \mathrm{~s}$. Chemical shifts are reported in parts per million relative to aqueous $\mathrm{Ga}\left(\mathrm{NO}_{3}\right)_{3}$ using either $\mathrm{LaGaO}_{3}\left(\delta_{\text {iso }}=57\right.$ ppm $)$ or $\mathrm{GaPO}_{4}$ berlinite $\left(\delta_{\text {iso }}=111.2 \mathrm{ppm}\right)$ as secondary solid references.

The calculation of NMR parameters was carried out using the CASTEP density functional theory (DFT) code (version 18.1), ${ }^{39}$ employing the gauge-including projector-augmented wave (GIPAW) approach $^{40}$ to reconstruct the all-electron wave function in the presence of a magnetic field. Calculations were performed using the GGA PBE functional, ${ }^{41}$ with dispersion corrections provided by the scheme of Tkatchenko and Scheffler. ${ }^{42,43}$ Ultrasoft pseudopotentials were used with the inclusion of ZORA scalar relativistic effects. (A modified pseudopotential was used for gallium; see the Supporting Information for more details.) A plane-wave energy cutoff of $60 \mathrm{Ry}$ $(\sim 816 \mathrm{eV})$ was used, and integrals over the first Brillouin zone were performed using a Monkhorst-Pack grid ${ }^{44}$ with a $k$-point spacing of 0.03 or $0.042 \pi \AA^{-1}$. Optimization of atomic coordinates and unit cell parameters was carried out prior to the calculation of NMR parameters. Calculations were performed on a computing cluster at the University of St Andrews, consisting of 90 32-core Intel Broadwell nodes, an Infiniband FDR interconnect, and a 300 TB GPFS distributed file system. Typical calculation times were between 3-10 $\mathrm{h}$ (geometry optimization) and $\sim 1 \mathrm{~h}$ (NMR parameters), using 48 cores. Isotropic shieldings, $\sigma_{\text {iso }}$, were obtained from the trace of the absolute shielding tensor, $\sigma$, and isotropic chemical shifts, $\delta_{\text {iso }}$, were given by $\delta_{\text {iso }}=-\left(\sigma_{\text {iso }}-\sigma_{\text {ref }}\right) / m$, where $\sigma_{\text {ref }}$ and $m$ had values of 562.4 ppm and 1.07 for ${ }^{27} \mathrm{Al}$ and $1740 \mathrm{ppm}$ and 1.01 for ${ }^{71} \mathrm{Ga}$, respectively (see the Supporting Information). The quadrupolar coupling constant $\left(C_{\mathrm{Q}}=e Q V_{Z Z} / h\right)$ and the asymmetry parameter $\left[\eta_{\mathrm{Q}}=\left(V_{X X}-V_{Y Y}\right) /\right.$ $\left.V_{Z Z}\right]$ are obtained directly from the principal components of the electric field gradient tensor, V. $Q$ is the nuclear quadrupole moment, ${ }^{45}$ for which values of 146.6 and $107 \mathrm{mb}$ were used for ${ }^{27} \mathrm{Al}$ and ${ }^{71} \mathrm{Ga}$, respectively.

\section{RESULTS AND DISCUSSION}

$\mathrm{Ga}_{5-x} \mathrm{Al}_{x} \mathrm{O}_{7}(\mathrm{OH})$. The hitherto unreported $\mathrm{Ga}_{5-x} \mathrm{Al}_{x} \mathrm{O}_{7}(\mathrm{OH})$ solid solution can be achieved for a composition range of $0 \leq x \leq 1.5$ from solvothermal reaction between $\mathrm{Ga}(\mathrm{acac})_{3}$ and $\mathrm{Al}\left(\mathrm{O}^{i} \mathrm{Pr}\right)_{3}$ in 1,4-butanediol for $96 \mathrm{~h}$ at $240{ }^{\circ} \mathrm{C}$. The synthesis method is similar to that reported by Inoue and co-workers, who used solvothermal reactions to prepare $\gamma-\mathrm{Ga}_{2-x} \mathrm{Al}_{x} \mathrm{O}_{3},{ }^{24}$ but we have used lower temperatures and extended reaction times. The previous synthetic work was performed at $300{ }^{\circ} \mathrm{C}$ for just $2 \mathrm{~h}$ in a nitrogen atmosphere, and the only products found in 1,4-butanediol were $\gamma-\mathrm{Ga}_{2-x} \mathrm{Al}_{x} \mathrm{O}_{3}$ materials $(x \leq 1.5)$. We found that shorter reaction times at $240{ }^{\circ} \mathrm{C}$ were unreliable as a synthesis route, yielding either $\gamma$ $\mathrm{Ga}_{2} \mathrm{O}_{3}$ with $\mathrm{AlOOH}, \gamma-\mathrm{Ga}_{2-x} \mathrm{Al}_{x} \mathrm{O}_{3}$, or $\mathrm{GaOOH}$. We found that the same reaction can be performed in 1,5-pentanediol, but the synthesis time must be even longer, requiring a minimum of 7 days, with shorter reaction times yielding only amorphous materials. Figure 1 shows powder XRD profiles fitted using the Pawley refinement method against data from $\mathrm{Ga}_{5-x} \mathrm{Al}_{x} \mathrm{O}_{7}(\mathrm{OH})$ samples with $x$ values of $0,0.5,1.0$, and 1.5 . These fits were performed using space group $P 6 \overline{3} \mathrm{mc}$, with initial lattice parameters from the published structure of $\mathrm{Ga}_{5} \mathrm{O}_{7}(\mathrm{OH}) .{ }^{15}$ Clear evidence of anisotropic peak broadening was found in all three samples, although this is less prominent with an increase in $\mathrm{Al}^{3+}$ content, as there is an increase in the overall level of static disorder within the material, such that all reflections are further broadened. The use of Stephens' phenomenological model of anisotropic peak broadening ${ }^{46}$ was essential to obtain a satisfactory profile fit. Figure 2 shows the evolution of the lattice parameters with Ga:Al ratio (see Table S1 for values of lattice parameters). The variation of the unit cell volume with elemental substitution follows Vegard's

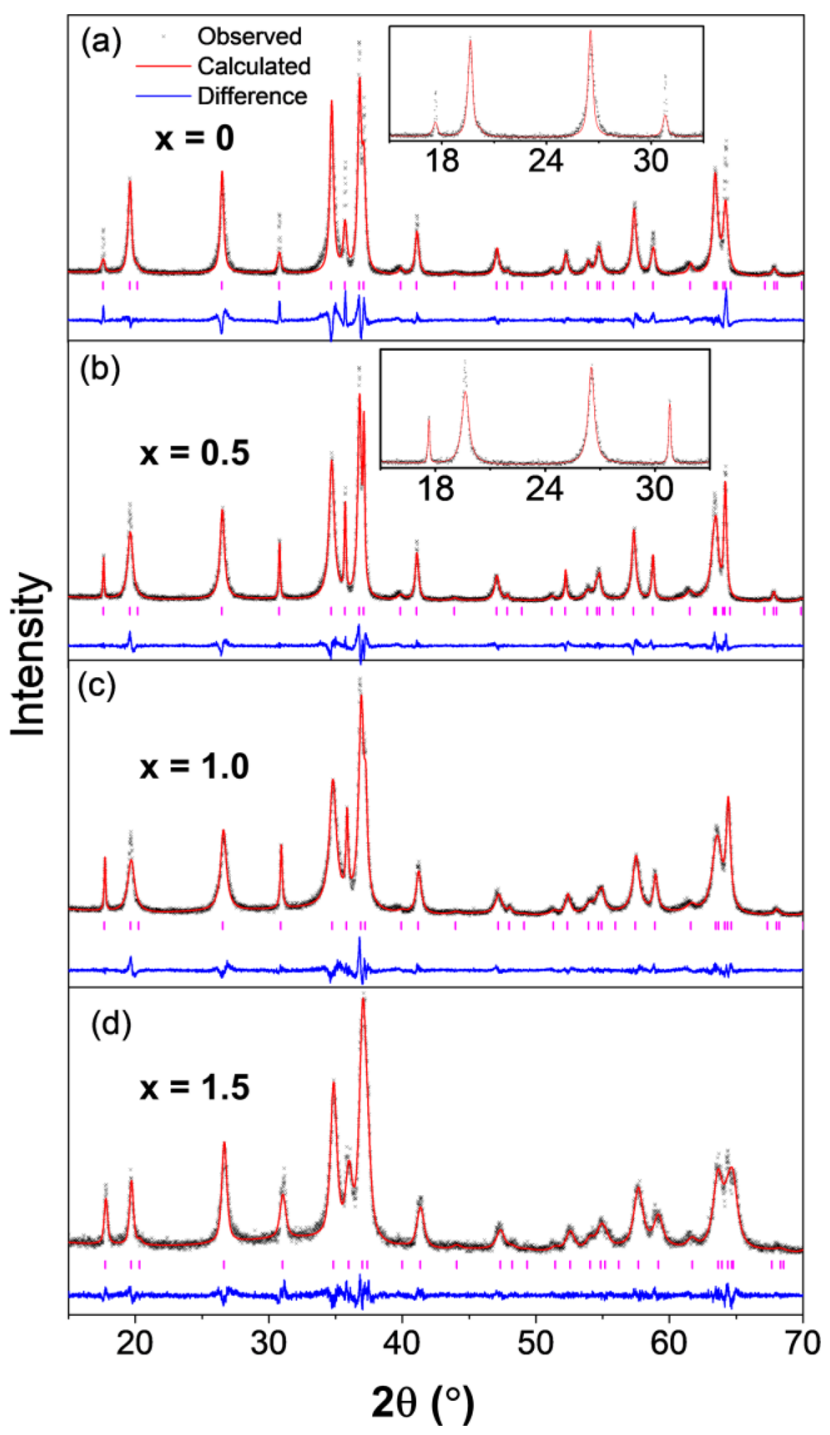

Figure 1. Pawley refinements against powder XRD data $(\lambda=1.54059$ $\AA)$ for $\mathrm{Ga}_{5-x} \mathrm{Al}_{x} \mathrm{O}_{7}(\mathrm{OH})(0 \leq x \leq 1.5)$, with insets showing the fit to a region of the data when the Stephens' parameters were not used to correct for anisotropic peak broadening.

law, with the volume of the material linearly decreasing with an increasing level of aluminum substitution. Infrared spectroscopy shows an intense $\mathrm{O}-\mathrm{H}$ stretching mode observed at 3300 $\mathrm{cm}^{-1}$ (Figure S1), and a feature at $850 \mathrm{~cm}^{-1}$ that is attributed to a $(\mathrm{Ga}, \mathrm{Al})-\mathrm{O}-\mathrm{H}$ bending mode, as a mode at a similar wavenumber was assigned to this in both $\mathrm{Ga}_{5} \mathrm{O}_{7}(\mathrm{OH})^{15}$ and in a computational study on $\mathrm{Al}_{5} \mathrm{O}_{7}(\mathrm{OH}) .{ }^{47}$ Solid-state ${ }^{1} \mathrm{H}$ NMR spectra of the $\mathrm{Ga}_{5-x} \mathrm{Al}_{x} \mathrm{O}_{7}(\mathrm{OH})$ materials (Figure S2) also confirm the presence of $(\mathrm{Ga}, \mathrm{Al})-\mathrm{OH}$ species, with chemical shifts between 7.7 and 8.0 ppm.

MacDonald et al. reported a phase they identified as $\mathrm{GaAlO}_{3}$ in 1967, and their refined lattice parameters $(a=5.70 \AA, c=$ $8.92 \AA$, and $\left.V=251.0 \AA^{3}\right)$, ${ }^{23}$ fit very well with the trend in unit cell volume seen in Figure 2. It seems likely the oxyhydroxides that we now report are related materials, with the earlier assignment of composition incorrect (note that the previous work used high-temperature hydrothermal synthesis, which may have given access to materials with a greater $\mathrm{Al}$ content than we have achieved). $\mathrm{Ga}_{5} \mathrm{O}_{7}(\mathrm{OH})$ and $\mathrm{Al}_{5} \mathrm{O}_{7}(\mathrm{OH})$ are forms of the mineral $5 \mathrm{Al}_{2} \mathrm{O}_{3} \cdot \mathrm{H}_{2} \mathrm{O}$, known as akdalaite, ${ }^{49}$ with a 

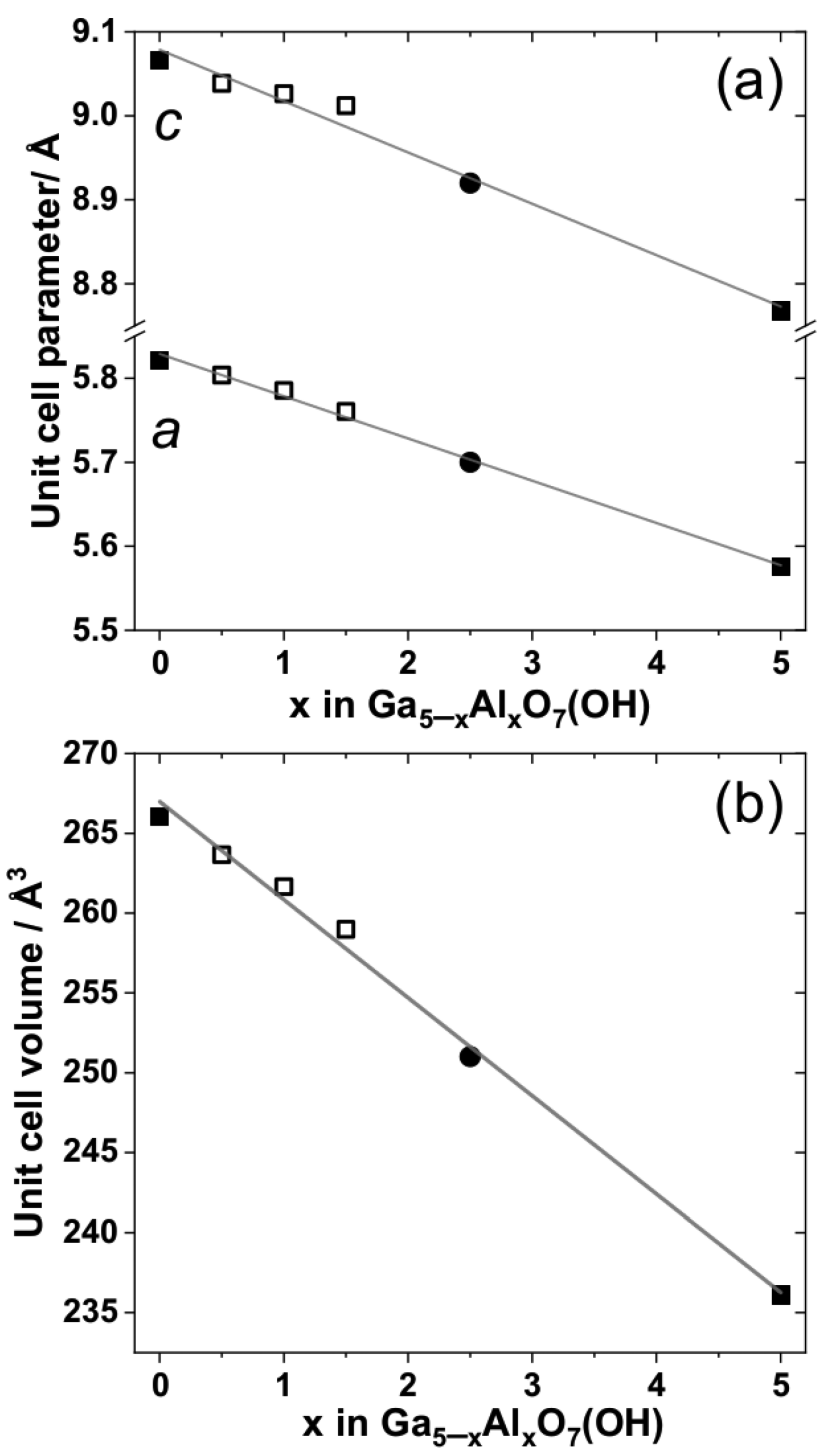

Figure 2. Plot of (a) hexagonal lattice parameters and (b) unit cell volume vs composition for $\mathrm{Ga}_{5-x} \mathrm{Al}_{x} \mathrm{O}_{7}(\mathrm{OH})$. The values for the end members $(\boldsymbol{\square})$ are taken from the literature for $x$ values of $0^{15}$ and $5 .^{48}$ The $x$ values of $0.5,1$, and $1.5(\square)$ were determined in this work, while the values of $2.5(\bullet)$ are those reported for "hexagonal $\mathrm{GaAlO}_{3}$ " by Macdonald et al. ${ }^{23}$ The linear fits (gray lines) are the result of linear regression analysis against all of the data points.

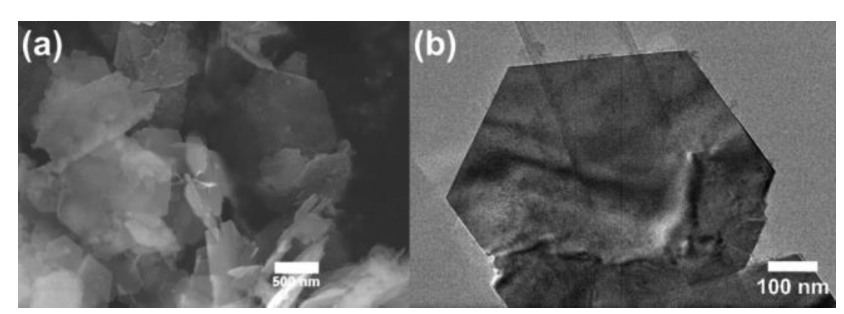

Figure 3. (a) SEM image and (b) TEM image of $\mathrm{Ga}_{3.5} \mathrm{Al}_{1.5} \mathrm{O}_{7}(\mathrm{OH})$.

synthetic form of the material initially described as tohdite. ${ }^{50,51}$ It is interesting to note that there are no reported non-aqueous solvothermal syntheses of $\mathrm{Al}_{5} \mathrm{O}_{7}(\mathrm{OH})$, and it is usually synthesized by treating aluminum salts, or aluminum oxides, hydrothermally at temperatures in excess of $240{ }^{\circ} \mathrm{C}$, typically with the application of external pressure. ${ }^{50} \mathrm{We}$ found that $\mathrm{Al}_{5} \mathrm{O}_{7}(\mathrm{OH})$ could not be prepared by reaction of either
$\mathrm{Al}\left(\mathrm{O}^{i} \mathrm{Pr}\right)_{3}$ or $\mathrm{Al}(\mathrm{acac})_{3}$ in 1,4 -butanediol at $240{ }^{\circ} \mathrm{C}$, despite a wide range of reaction times being investigated.

TGA of $\mathrm{Ga}_{3.5} \mathrm{Al}_{1.5} \mathrm{O}_{7}(\mathrm{OH})$ shows that a gradual mass loss of $1.5 \%$ commences immediately upon heating to $\sim 400{ }^{\circ} \mathrm{C}$, followed by a larger mass loss of $2.5 \%$ occurring between 400 and $600{ }^{\circ} \mathrm{C}$ (Figure S3). This second mass loss is consistent with the dehydration of $\mathrm{Ga}_{3.5} \mathrm{Al}_{1.5} \mathrm{O}_{7}(\mathrm{OH})$ because it occurs over the same temperature range over which the material is observed to decompose in the thermodiffractometry experiment (see below), and the mass loss of $2.5 \%$ is consistent with the expected mass loss of $\sim 2.2 \%$ on conversion to " $\mathrm{Ga}_{1.4} \mathrm{Al}_{0.6} \mathrm{O}_{3}$ ". The first observed gradual mass loss could possibly be attributed to the loss of excess surface diol. TEM shows that $\mathrm{Ga}_{3.5} \mathrm{Al}_{1.5} \mathrm{O}_{7}(\mathrm{OH})$ consists of large, thin hexagonal plates (Figure 3 ). The anisotropic peak broadening observed by XRD is likely a consequence of the morphology of the material, as was also reported for the pure gallium analogue. ${ }^{15}$

The structure of $\mathrm{Ga}_{5} \mathrm{O}_{7}(\mathrm{OH})$ contains both tetrahedral and octahedral sites for the trivalent cations, occupied in a 1:4 ratio. ${ }^{15}$ Given the different coordination preferences of $\mathrm{Al}$ and Ga, solid-state NMR spectroscopy was used to determine the relative proportion of each site occupied in the samples of $\mathrm{Ga}_{5-x} \mathrm{Al}_{x} \mathrm{O}_{7}(\mathrm{OH})$ with $x$ values of $0,0.5,1$, and 1.5 .

In oxides, the ${ }^{27} \mathrm{Al}$ isotropic chemical shift ranges for tetrahedral and octahedral coordination environments are well separated at 80 to 50 and 15 to $-10 \mathrm{ppm}$, respectively. ${ }^{52}$ In principle, the same is true for ${ }^{71} \mathrm{Ga} N M R$, which has isotropic chemical shift ranges of approximately 220 to $110 \mathrm{ppm}$ and approximately 80 to $-40 \mathrm{ppm}$ for tetrahedrally and octahedrally coordinated $\mathrm{Ga}$, respectively, ${ }^{52}$ but the larger second-order quadrupolar broadening usually requires the use of higher external magnetic fields (here, $B_{0}=20.0 \mathrm{~T}$ ) to afford sufficiently high resolution to allow accurate quantitation of these species. ${ }^{16}$ Figure 4 a shows the ${ }^{71}$ Ga MAS NMR spectrum of $\mathrm{Ga}_{5} \mathrm{O}_{7}(\mathrm{OH})$, which contains three resonances with NMR parameters listed in Table 1 (indicated by the red and gray lines in Figure 4a). These resonances can be assigned by their isotropic chemical shifts and relative intensities to octahedral Ga1 $\left(\delta_{\text {iso }}=80 \mathrm{ppm}\right)$, octahedral Ga2 $\left(\delta_{\text {iso }}=20 \mathrm{ppm}\right)$, and tetrahedral $\mathrm{Ga} 3\left(\delta_{\text {iso }}=132 \mathrm{ppm}\right)$ in the structure of $\mathrm{Ga}_{5} \mathrm{O}_{7}(\mathrm{OH})$ reported by Playford et al. ${ }^{15}$ The relatively small quadrupolar coupling constant $\left(C_{\mathrm{Q}}\right)$ observed for $\mathrm{Ga} 2$ indicates that its coordination environment is close to ideal, whereas the much larger $C_{\mathrm{Q}}$ observed for Gal reflects the fact that this site is coordinated by five oxides and one hydroxide, leading to a lowering of the local symmetry, a distortion of the coordination environment, and a much larger electric field gradient (EFG, responsible for the magnitude of $C_{Q}{ }^{53}$ ) at the $\mathrm{Ga}$ site. Interestingly, the signal attributed to tetrahedral $\mathrm{Ga} 3$ also displays a very large $C_{\mathrm{Q}}$ compared to that of the $\beta$ polymorph of $\mathrm{Ga}_{2} \mathrm{O}_{3}\left(\sim 11 \mathrm{MHz}\right.$ for the tetrahedral site) ${ }^{16}$ However, it can be seen from the structure of Playford et al. ${ }^{15}$ that this site in $\mathrm{Ga}_{5} \mathrm{O}_{7}(\mathrm{OH})$ is significantly distorted, with $\mathrm{O}-$ $\mathrm{Ga}-\mathrm{O}$ angles ranging from $102^{\circ}$ to $115^{\circ}$.

Panels $b$ and $c$ of Figure 4 show ${ }^{71} \mathrm{Ga}$ and ${ }^{27} \mathrm{Al}$ MAS NMR spectra of $\mathrm{Ga}_{5-x} \mathrm{Al}_{x} \mathrm{O}_{7}(\mathrm{OH})(x=0.5,1.0$, and 1.5). It is particularly apparent from the ${ }^{27} \mathrm{Al}$ NMR spectra that the $\mathrm{Al}$ shows a strong preference for substitution in the octahedral sites, with an $\mathrm{Al}^{\mathrm{IV}}: \mathrm{Al}^{\mathrm{VI}}$ ratio of $\sim 1: 220$ observed for $\mathrm{Ga}_{3.5} \mathrm{Al}_{1.5} \mathrm{O}_{7}(\mathrm{OH})$ (cf. 1:4 for random substitution). Interpreting the ${ }^{71} \mathrm{Ga}$ NMR spectra is more challenging as the resonances are not as well resolved as for ${ }^{27} \mathrm{Al}$, and the signal from tetrahedral Ga3 is so broad that it is difficult to detect 
(a)

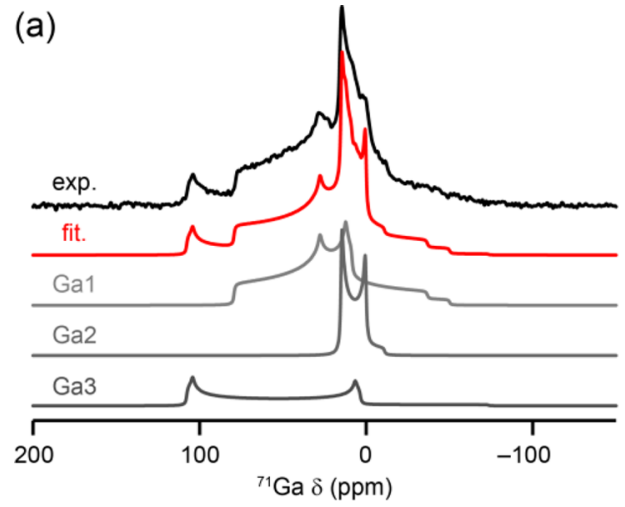

(c)

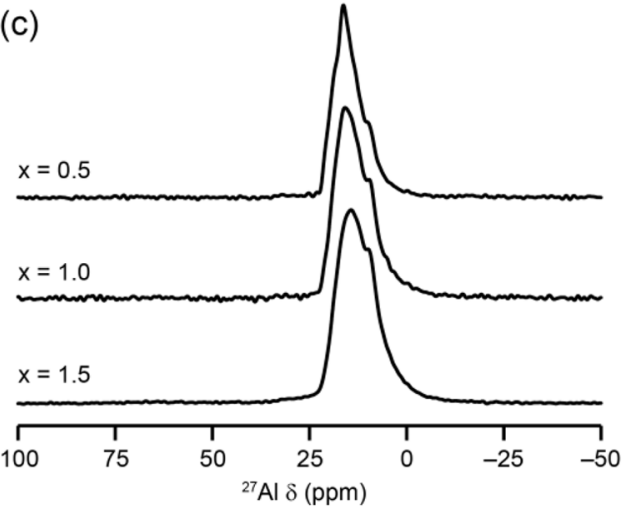

(b)

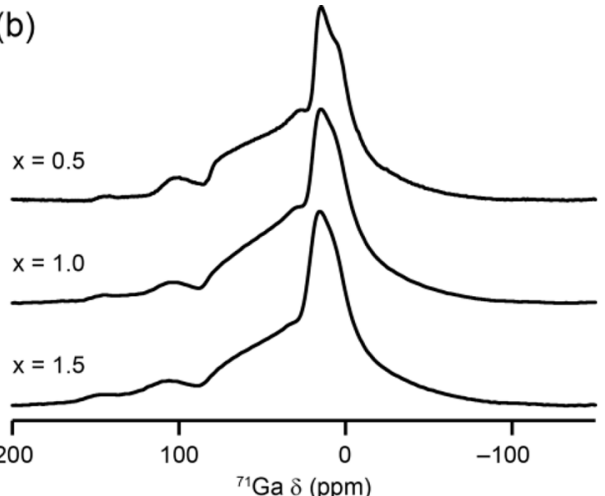

(d)

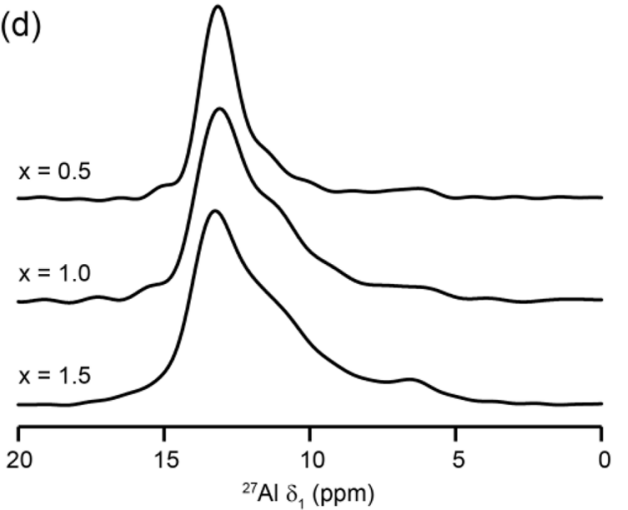

Figure 4. (a) ${ }^{71} \mathrm{Ga}\left(20.0 \mathrm{~T}, 75 \mathrm{kHz}\right.$ MAS) NMR spectrum of $\mathrm{Ga}_{5} \mathrm{O}_{7}(\mathrm{OH})$ (black), spectrum simulated using the parameters given in Table 1 (red), and individual line shapes corresponding to the three Ga signals (gray). (b) ${ }^{71} \mathrm{Ga}\left(20.0 \mathrm{~T}, 55 \mathrm{kHz}\right.$ MAS) NMR spectra, (c) ${ }^{27} \mathrm{Al}(14.1 \mathrm{~T}, 20 \mathrm{kHz}$ MAS) NMR spectra, and (d) $\delta_{1}$ projections of ${ }^{27} \mathrm{Al}(14.1 \mathrm{~T}, 20 \mathrm{kHz}$ MAS) MQMAS NMR spectra (see Figure S4 for two-dimensional spectra) of $\mathrm{Ga}_{5-x} \mathrm{Al}_{x} \mathrm{O}_{7}(\mathrm{OH})(x=0.5,1.0$, and 1.5$)$.

Table 1. ${ }^{71} \mathrm{Ga}$ NMR Parameters of $\mathrm{Ga}_{5} \mathrm{O}_{7}(\mathrm{OH})$ Obtained from Fitting the Spectrum in Figure $4 a$

$\begin{array}{ccccc}\text { site } & \text { relative integral } & \delta_{\text {iso }}(\mathrm{ppm}) & C_{\mathrm{Q}}(\mathrm{MHz}) & \eta_{\mathrm{Q}} \\ \mathrm{Ga} 1 & 3.0 & 81(2) & 11.3(2) & 0.75(5) \\ \mathrm{Ga} 2 & 1.0 & 20(2) & 5.7(2) & 0.05(5) \\ \mathrm{Ga} 3 & 1.0 & 132(5) & 15.0(2) & 0.05(2)\end{array}$

Table 2. ${ }^{27} \mathrm{Al}$ NMR Parameters of $\mathrm{Ga}_{5-x} \mathrm{Al}_{x} \mathrm{O}_{7}(\mathrm{OH})$ Obtained from the MQMAS Spectra Shown in Figure S4 (and the corresponding projections shown in Figure 4d)

\begin{tabular}{|c|c|c|c|c|c|c|}
\hline & \multicolumn{2}{|c|}{$\mathrm{Ga}_{4.5} \mathrm{Al}_{0.5} \mathrm{O}_{7} \mathrm{OH}$} & \multicolumn{2}{|c|}{$\mathrm{Ga}_{4.0} \mathrm{Al}_{1.0} \mathrm{O}_{7} \mathrm{OH}$} & \multicolumn{2}{|c|}{$\mathrm{Ga}_{3.5} \mathrm{Al}_{1.5} \mathrm{O}_{7} \mathrm{OH}$} \\
\hline & $\begin{array}{c}\left\langle\delta_{\text {iso }}\right\rangle \\
(\mathrm{ppm})\end{array}$ & $\begin{array}{c}\left\langle P_{\mathrm{Q}}\right\rangle \\
(\mathrm{MHz})\end{array}$ & $\begin{array}{c}\left\langle\delta_{\text {iso }}\right\rangle \\
(\mathrm{ppm})\end{array}$ & $\begin{array}{c}\left\langle P_{\mathrm{Q}}\right\rangle \\
(\mathrm{MHz})\end{array}$ & $\begin{array}{c}\left\langle\delta_{\text {iso }}\right\rangle \\
(\mathrm{ppm})\end{array}$ & $\begin{array}{c}\left\langle P_{\mathrm{Q}}\right\rangle \\
(\mathrm{MHz})\end{array}$ \\
\hline signal I & $21(1)$ & $4.6(2)$ & $21(1)$ & $4.7(2)$ & $20(1)$ & $5.1(2)$ \\
\hline signal II & $20(1)$ & $3.5(2)$ & $19(1)$ & $3.8(2)$ & $18(1)$ & $3.8(2)$ \\
\hline signal III & $11(1)$ & $2.2(2)$ & $11(1)$ & $2.1(2)$ & $11(1)$ & $2.1(2)$ \\
\hline
\end{tabular}

visually that its relative proportion is increasing. Accurate spectral decomposition also becomes more challenging as the local disorder introduced by $\mathrm{Al}$ leads to further broadening of the spectral resonances. High-resolution ${ }^{27} \mathrm{Al}$ multiplequantum (MQ) MAS NMR spectra were recorded for these materials, and the isotropic $\left(\delta_{1}\right)$ projections are shown in Figure $4 d$ (see Figure S4 for the two-dimensional spectra). Surprisingly, the MQMAS spectra reveal three signals for octahedral $\mathrm{Al}$ for all three compositions. While it is not possible to extract $\delta_{\text {iso }}$ and $C_{\mathrm{Q}}$ directly from the MQMAS spectrum of a disordered material (owing to the distribution of these two parameters arising from the inherent distribution of chemical sites present), ${ }^{54}$ the position of the center of gravity of a resonance within the spectrum can still provide information about the mean chemical shift, $\left\langle\delta_{\text {iso }}\right\rangle$, and mean quadrupolar product, ${ }^{53}\left\langle P_{\mathrm{Q}}\right\rangle$, where

$$
P_{\mathrm{Q}}=C_{\mathrm{Q}}\left[1+\left(\frac{\eta_{\mathrm{Q}}}{3}\right)^{2}\right]^{1 / 2}
$$

Table 2 reports these mean values for the three resonances observed for each of the three samples of $\mathrm{Ga}_{5-x} \mathrm{Al}_{x} \mathrm{O}_{7}(\mathrm{OH})$. The first, signal I, has values of $\left\langle\delta_{\text {iso }}\right\rangle$ and $\left\langle P_{\mathrm{Q}}\right\rangle$ similar to those predicted for substitution of $\mathrm{Al}$ onto site 1 and signal III values similar to those predicted for substitution onto site 2. Signal II, however, has a $\left\langle\delta_{\text {iso }}\right\rangle$ value consistent with substitution onto site 1 but a different $\left\langle P_{\mathrm{Q}}\right\rangle$, suggesting some variation in the local or medium-range environment.

DFT calculations can often be used to provide insight into the NMR spectra of disordered materials where the disorder arises from simple substitutions of one atom for another, ${ }^{54}$ as is expected to be the case for $\mathrm{Ga}_{5-x} \mathrm{Al}_{x} \mathrm{O}_{7} \mathrm{OH}$. In this case, seven model structures were generated by substituting one or two $\mathrm{Al}$ atoms into the structure of $\mathrm{Ga}_{5} \mathrm{O}_{7} \mathrm{OH}$ of Playford et al., ${ }^{15}$ corresponding to $10 \%$ or $20 \% \mathrm{Al}$ substitution, respectively. For further details of the model structures, see section S2 of the Supporting Information. All models were optimized prior to calculation of the reported energies and NMR parameters. When considering the model structures with one $\mathrm{Al}$ per unit cell, substitution onto site 1 (i.e., Ga1) is most energetically 


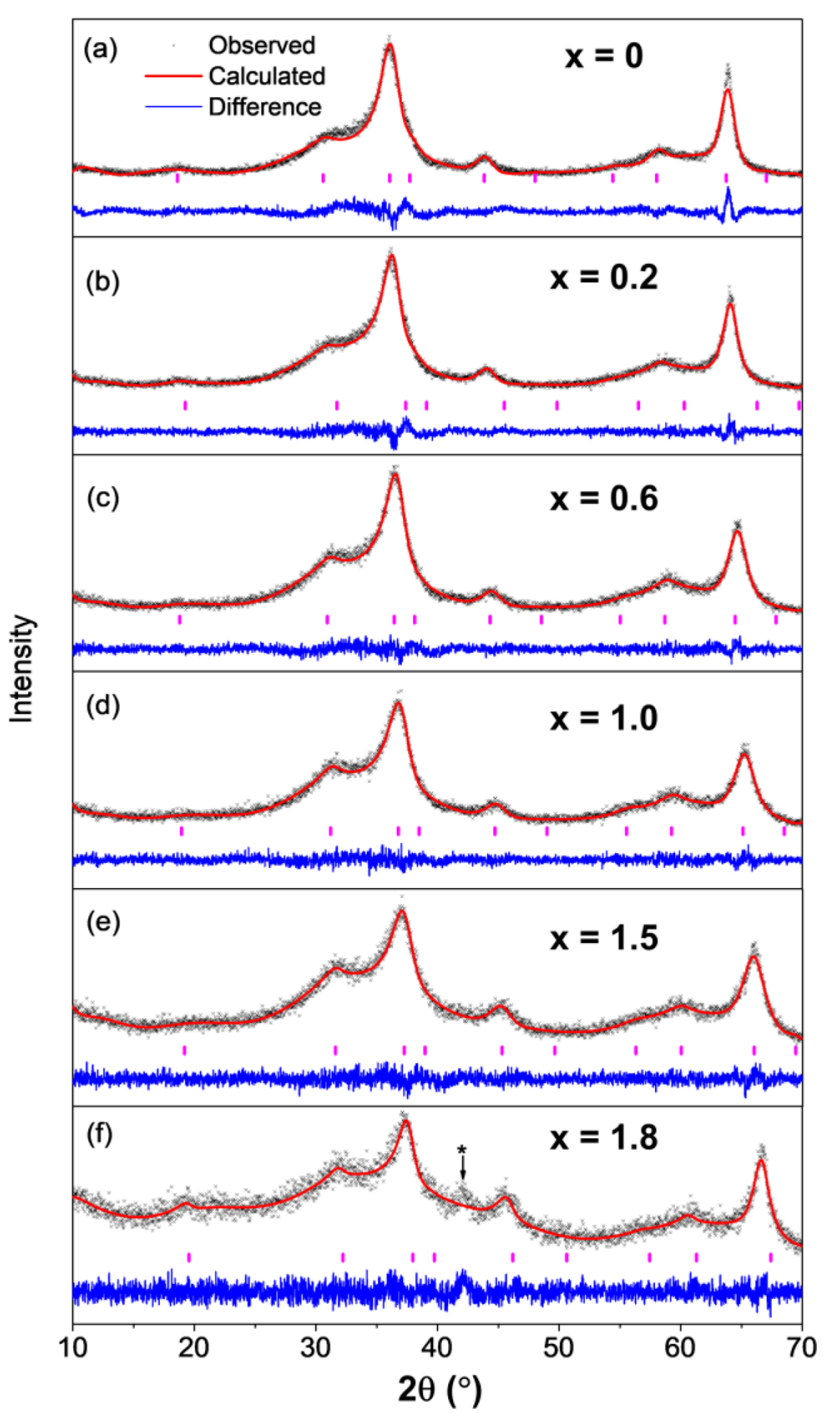

Figure 5. Pawley refinements against powder XRD data $(\lambda=1.54059$ $\AA)$ for $\gamma-\mathrm{Ga}_{2-x} \mathrm{Al}_{x} \mathrm{O}_{3}$ spinels $(0 \leq x \leq 1.8)$. The asterisk denotes an impurity phase in the $x=1.8$ material.

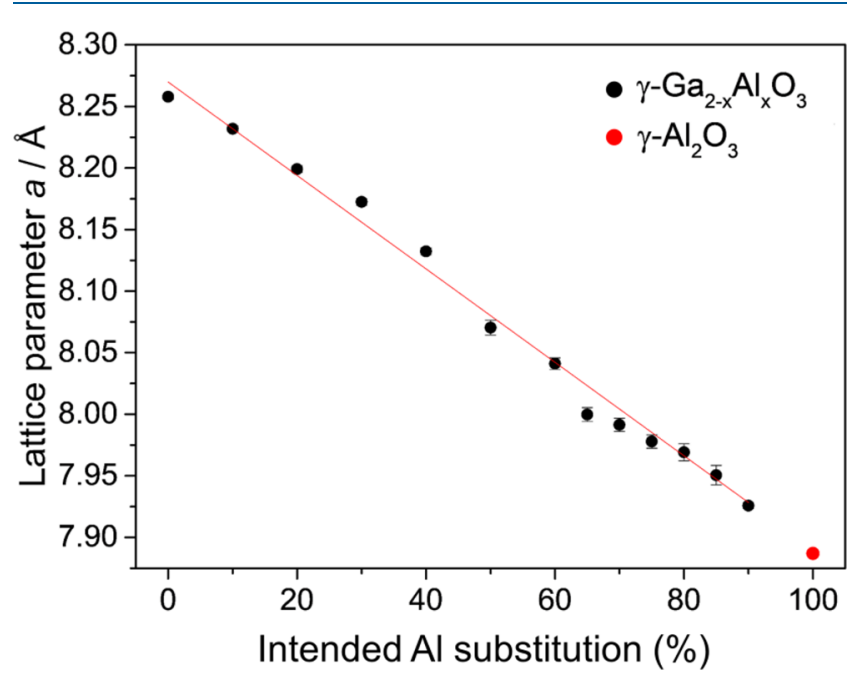

Figure 6. Plot of the spinel lattice parameter for $\gamma-\mathrm{Ga}_{2-x} \mathrm{Al}_{x} \mathrm{O}_{3}$ with increasing aluminum substitution and comparison to that of a reference $\gamma-\mathrm{Al}_{2} \mathrm{O}_{3}$ material. ${ }^{55}$

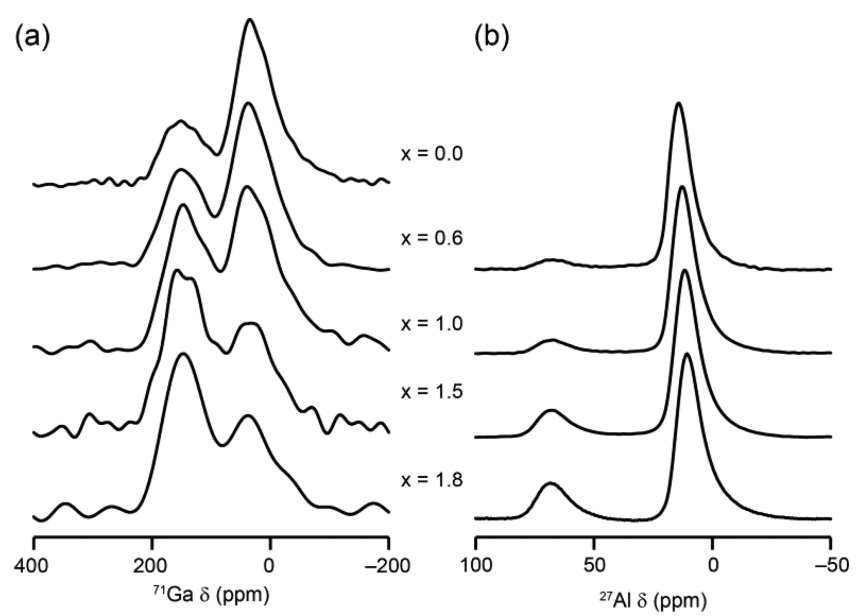

Figure 7. (a) ${ }^{71} \mathrm{Ga}\left(20.0 \mathrm{~T}, 75 \mathrm{kHz}\right.$ MAS) NMR spectra and (b) ${ }^{27} \mathrm{Al}$ (14.1 T, $20 \mathrm{kHz}$ MAS) NMR spectra of $\gamma-\mathrm{Ga}_{2-x} \mathrm{Al}_{x} \mathrm{O}_{3}$.

favored [by $0.215 \mathrm{eV}$ per cell $\left(10.4 \mathrm{~kJ} \mathrm{~mol}^{-1}\right)$ relative to $\mathrm{Ga} 2$ and $0.519 \mathrm{eV}$ per cell $\left(25.0 \mathrm{~kJ} \mathrm{~mol}^{-1}\right)$ relative to Ga3]. Given the greater energetic preference for substitution for Ga1, as well as the greater number of these sites in the crystal structure, it is unsurprising that a significant amount of All is observed in experimental NMR spectra and that $\mathrm{Al} 3$ is not observed at all. However, experimentally an additional resonance is observed in the ${ }^{27} \mathrm{Al}$ MQMAS spectrum, even for the sample with the lowest $\mathrm{Al}$ content, perhaps suggesting that the $\mathrm{Al}$ atoms adopt some degree of ordering or clustering.

By including two $\mathrm{Al}$ atoms per cell, we are able to investigate the effects of their relative positions on the calculated ${ }^{27} \mathrm{Al}$ NMR parameters. Again, it is seen that placing the second $\mathrm{Al}$ also on site 1 is most energetically favorable $(0.276 \mathrm{eV}$ per cell relative to Al1 and $\mathrm{Al} 2$ and $0.556 \mathrm{eV}$ per cell relative to $\mathrm{All}$ and $\mathrm{Al} 3$ ) and that the two possible relative positions of All and Al1 (i.e., bridged by $\mathrm{Al}-\mathrm{OH}-\mathrm{Al}$ or isolated) are energetically very similar (with a difference of only $0.060 \mathrm{eV}$ per cell). However, the values of $C_{\mathrm{Q}}$ calculated for these two atomic arrangements are quite different, with the $\mathrm{Al}$ in an $\mathrm{All}-\mathrm{OH}-\mathrm{All}$ motif having a $C_{\mathrm{Q}}$ of $5.0 \mathrm{MHz}$ and two isolated All atoms having a $\mathrm{C}_{\mathrm{Q}}$ of $3.4 \mathrm{MHz}$ (compared to $4.7 \mathrm{MHz}$ for a single isolated Al1 in the cell). This suggests that signals I and II in Table 2 can be assigned to All-OH-All and isolated All, respectively. The presence of $\mathrm{Al} 2$ in the same cell as $\mathrm{All}$ is predicted to lead to an even smaller $C_{\mathrm{Q}}$ for All of $2.8 \mathrm{MHz}$, and while a clear resonance is not observed for this species (because of the low Al population on site 2 ), such species may be responsible for the tail to lower $\delta_{1}$ seen in Figure $4 \mathrm{~d}$. The ${ }^{27} \mathrm{Al}$ NMR spectra, therefore, can be seen as evidence that $\mathrm{Al}$ has a strong preference for site 1 and $\mathrm{Al}$ cannot be homogeneously distributed throughout the material as, even for the lowest $\mathrm{Al}$ content $\left(\mathrm{Ga}_{4.5} \mathrm{Al}_{0.5} \mathrm{O}_{7} \mathrm{OH}\right)$, a signal is observed for $\mathrm{All}$ near the other All (i.e., Al-rich regions).

It should also be noted in the ${ }^{71} \mathrm{Ga}$ MAS NMR spectra of $\mathrm{Ga}_{5-x} \mathrm{Al}_{x} \mathrm{O}_{5} \mathrm{OH}$, shown in Figure $4 \mathrm{~b}$, that an additional resonance at $\sim 145 \mathrm{ppm}$ is observed. There is no evidence from any of the calculations that $\mathrm{Al}$ substitution should give rise to a resonance in this position, and the most likely assignment is that it is part of the line shape for the tetrahedral $\mathrm{Ga}$ in a minor impurity of $\beta-\mathrm{Ga}_{2-x} \mathrm{Al}_{x} \mathrm{O}_{3}$ (see below for further discussion of this phase).

$\gamma-\mathrm{Ga}_{2-x} \mathrm{Al}_{x} \mathrm{O}_{3}$. The synthesis of $\gamma-\mathrm{Ga}_{2-x} \mathrm{Al}_{x} \mathrm{O}_{3}$ in $1,4-$ butanediol at $240{ }^{\circ} \mathrm{C}$ was found to be rather unreliable at 
Table 3. Relative Occupation of Tetrahedral and Octahedral Sites in $\gamma-\mathrm{Ga}_{2-x} \mathrm{Al}_{x} \mathrm{O}_{3}$ as Determined from the ${ }^{27} \mathrm{Al}$ and ${ }^{71} \mathrm{Ga} \mathrm{MAS}$ NMR Spectra in Figure 7 and Overall Formulas (represented in defect spinel and $\mathrm{AB}_{2} \mathrm{O}_{4}$ notation) Derived from Them

\begin{tabular}{|c|c|c|c|c|c|c|}
\hline \multirow[b]{2}{*}{$x$} & \multirow{2}{*}{$\frac{{ }^{27} \mathrm{Al} \mathrm{NMR}}{\% \mathrm{Al}^{\mathrm{IV}}}$} & \multicolumn{3}{|c|}{${ }^{71}$ Ga NMR } & \multicolumn{2}{|c|}{ formula } \\
\hline & & $\% \mathrm{Al}^{\mathrm{VI}}$ & $\% \mathrm{Ga}^{\mathrm{IV}}$ & $\% \mathrm{Ga}^{\mathrm{VI}}$ & defect spinel & $\mathrm{AB}_{2} \mathrm{O}_{4}$ \\
\hline 0.0 & - & - & 26.8 & 73.2 & $\gamma-\left(\mathrm{Ga}_{0.535}\right)^{\mathrm{tet}}\left[\mathrm{Ga}_{1.465}\right]^{\text {oct }} \mathrm{O}_{3}$ & $\left(\mathrm{Ga}_{0.713}\right)^{\text {tet }}\left[\mathrm{Ga}_{1.953}\right]^{\text {oct }} \mathrm{O}_{4}$ \\
\hline 0.6 & 5.2 & 94.8 & 33.6 & 66.4 & $\gamma-\left(\mathrm{Ga}_{0.470} \mathrm{Al}_{0.031}\right)^{\text {tet }}\left[\mathrm{Ga}_{0.930} \mathrm{Al}_{0.569}\right]^{\text {oct }} \mathrm{O}_{3}$ & $\left(\mathrm{Ga}_{0.626} \mathrm{Al}_{0.419}\right)^{\text {tet }}\left[\mathrm{Ga}_{1.24} \mathrm{Al}_{0.759}\right]^{\text {oct }} \mathrm{O}_{4}$ \\
\hline 1.0 & 7.7 & 92.3 & 39.3 & 60.7 & $\gamma-\left(\mathrm{Ga}_{0.393} \mathrm{Al}_{0.077}\right)^{\text {tet }}\left[\mathrm{Ga}_{0.607} \mathrm{Al}_{0.923}\right]^{\text {oct }} \mathrm{O}_{3}$ & $\left(\mathrm{Ga}_{0.524} \mathrm{Al}_{0.103}\right)^{\text {tet }}\left[\mathrm{Ga}_{0.809} \mathrm{Al}_{1.23}\right]^{\text {oct }} \mathrm{O}_{4}$ \\
\hline 1.5 & 14.7 & 85.3 & 63.5 & 36.5 & $\gamma-\left(\mathrm{Ga}_{0.318} \mathrm{Al}_{0.221}\right)^{\text {tet }}\left[\mathrm{Ga}_{0.183} \mathrm{Al}_{1.28}\right]^{\text {oct }} \mathrm{O}_{3}$ & $\left(\mathrm{Ga}_{0.424} \mathrm{Al}_{0.295}\right)^{\text {tet }}\left[\mathrm{Ga}_{0.244} \mathrm{Al}_{1.706}\right]^{\text {oct }} \mathrm{O}_{4}$ \\
\hline 1.8 & 19.4 & 80.6 & 61.8 & 38.2 & $\gamma-\left(\mathrm{Ga}_{0.124} \mathrm{Al}_{0.349}\right)^{\text {tet }}\left[\mathrm{Ga}_{0.076} \mathrm{Al}_{1.45}\right]^{\text {oct }} \mathrm{O}_{3}$ & $\left(\mathrm{Ga}_{0.165} \mathrm{Al}_{0.465}\right)^{\text {tet }}\left[\mathrm{Ga}_{0.101} \mathrm{Al}_{1.935}\right]^{\text {oct }} \mathrm{O}_{4}$ \\
\hline
\end{tabular}
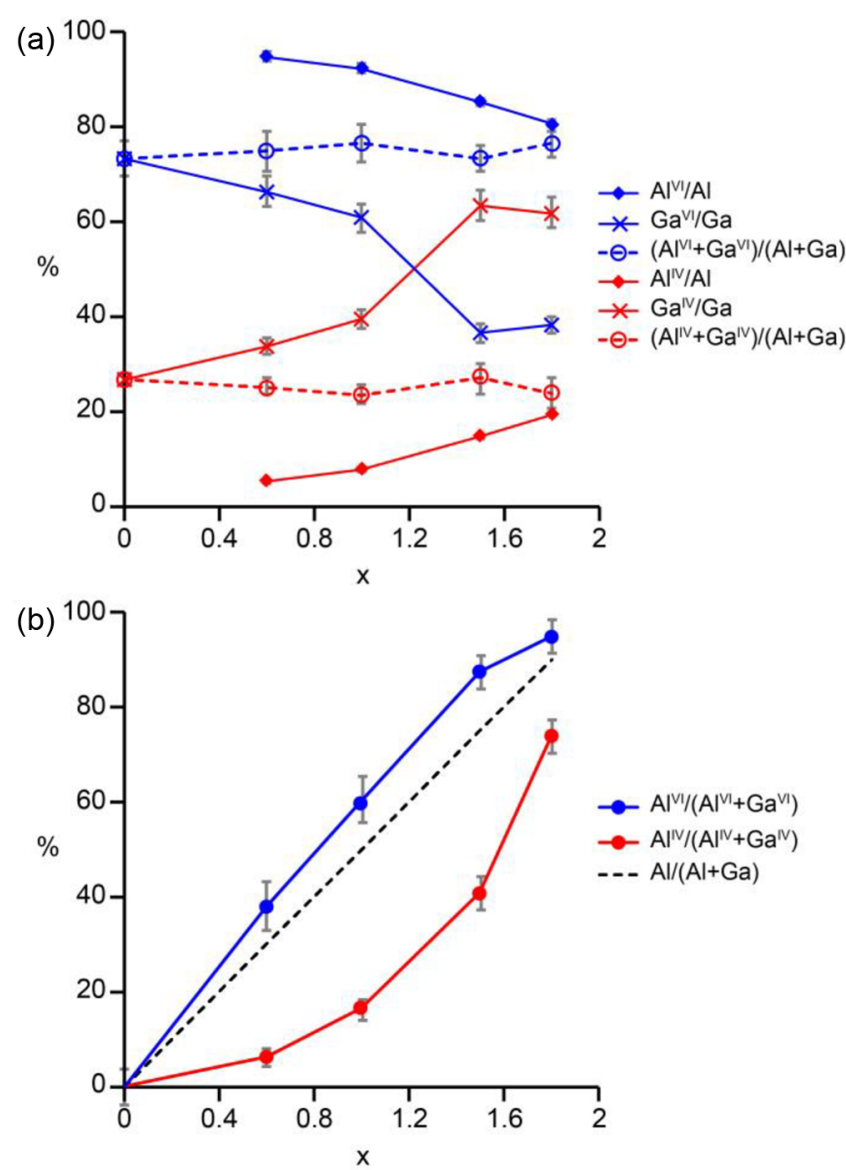

Figure 8. (a) Plot showing the proportion of tetrahedral (IV) and octahedral (VI) Al and Ga cations (solid lines and symbols), and the overall proportion of octahedral and tetrahedral cations (dashed lines), in $\gamma-\mathrm{Ga}_{2-x} \mathrm{Al}_{x} \mathrm{O}_{3}$. (b) Plot showing the amount of $\mathrm{Al}$ substitution on the tetrahedral and octahedral sites (solid lines) and the overall level of $\mathrm{Al}$ substitution in $\gamma-\mathrm{Ga}_{2-x} \mathrm{Al}_{x} \mathrm{O}_{3}$ (dashed line). All values were derived from the integrated spectral intensities from the ${ }^{27} \mathrm{Al}$ and ${ }^{71} \mathrm{Ga}$ NMR spectra shown in Figure 7.

short reaction times, often forming unwanted byproducts, such as $\mathrm{AlOOH}$ (boemite) and diaspore-type $\mathrm{GaOOH}$ (tsumgallite). However, changing the solvent to isopropanol was found to provide a reliable route to $\gamma-\mathrm{Ga}_{2-x} \mathrm{Al}_{x} \mathrm{O}_{3}$ spinels, and solid solutions containing up to $90 \% \mathrm{Al}^{3+}$ could be obtained (i.e., $x$ $\leq 1.8$ ). This exceeds the compositional range reported by Inoue and co-workers in their higher-temperature synthesis in 1,4-butanediol. ${ }^{24}$ The use of isopropanol may allow better mixing of the regents due to its lower viscosity. The XRD profiles (Figure 5) show that these materials have very broad Bragg reflections indicative of poorly crystalline materials and likely consist of nanosized crystallites. Scherrer analysis of the

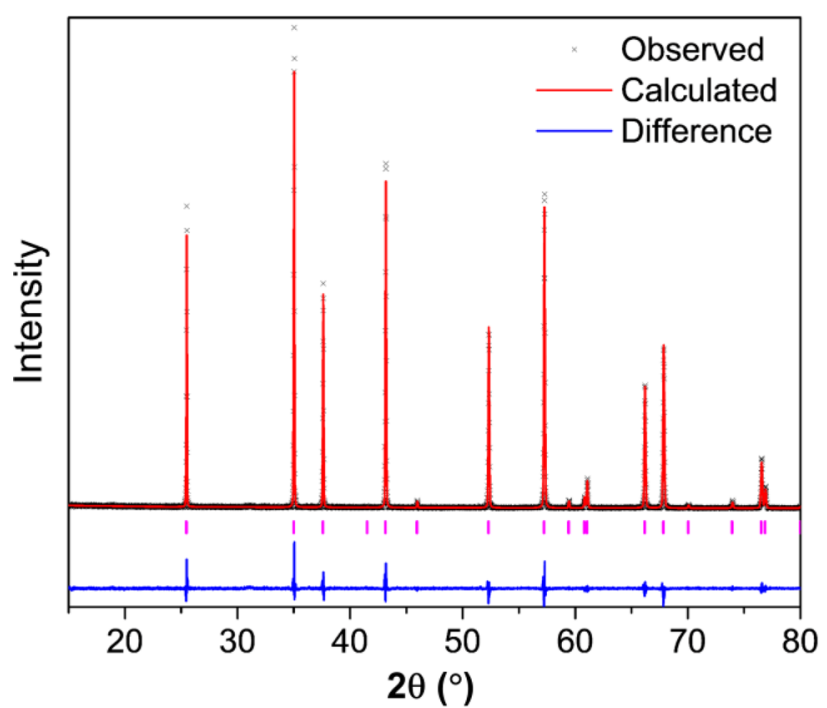

Figure 9. Rietveld plot of $\alpha$ - $\mathrm{Ga}_{0.2} \mathrm{Al}_{1.8} \mathrm{O}_{3}$ against powder $\mathrm{X}$-ray diffraction data $(\lambda=1.54059 \AA)$.

peak broadening gives estimated crystallite domain sizes ranging from $\sim 10 \mathrm{~nm}(x=0)$ to $\sim 7 \mathrm{~nm}(x=1.8)$, confirming the nanocrystalline nature of the materials. BET surface area measurements confirmed that all of these materials have a very large surface area of $\sim 200 \mathrm{~m}^{2} \mathrm{~g}^{-1}$. The powder XRD profiles can be fitted to a cubic crystal system in space group $F d \overline{3} m$, typical for spinel oxides, and Pawley refinements allowed the unit cell lattice parameter to be refined, revealing a linear decrease in this with an increase in $\mathrm{Al}^{3+}$ content (Figure 6). A peak due to an unidentified impurity around a $2 \theta$ of $42.5^{\circ}$ is prominent in the $90 \% \mathrm{Al}^{3+}$-substituted spinel, indicating that $90 \%$ has likely reached the limit of substitution in this solid solution by this synthesis method. No Rietveld analysis was undertaken because of the broadness of the peaks. EDX using SEM gives good agreement with the expected metal ratios in the samples (see Table S6).

The ${ }^{71} \mathrm{Ga}$ and ${ }^{27} \mathrm{Al}$ MAS NMR spectra of $\gamma-\mathrm{Ga}_{2-x} \mathrm{Al}_{x} \mathrm{O}_{3}$ are shown in Figure 7. All spectra contain broadened resonances with characteristic tails to lower shift, indicative of static disorder. For ${ }^{71} \mathrm{Ga}$, it should be noted that the signal-to-noise ratio is lower for samples with greater $\mathrm{Al}$ content owing to a combination of the low Ga content and the very small volume $(\sim 0.8 \mu \mathrm{L})$ of the $1 \mathrm{~mm}$ rotors required to achieve the rapid MAS rate. As for the $\mathrm{Ga}_{5-x} \mathrm{Al}_{x} \mathrm{O}_{7}(\mathrm{OH})$ series described above, the $\mathrm{Al}$ in $\gamma-\mathrm{Ga}_{2-x} \mathrm{Al}_{x} \mathrm{O}_{3}$ exhibits a strong preference for octahedral coordination and even with $90 \% \mathrm{Al}$ substitution $(x$ $=1.8$ ), $95 \%$ of the octahedral cations are $\mathrm{Al}$, but only $74 \%$ of the tetrahedral cations. This is consistent with earlier work by Areán et al., ${ }^{56}$ who used ${ }^{27} \mathrm{Al}$ and ${ }^{71} \mathrm{Ga}$ MAS NMR spectroscopy to characterize $\gamma-\mathrm{Ga}_{2-x} \mathrm{Al}_{x} \mathrm{O}_{3}$ with $x=0.4,1.0$, 
Table 4. Refined Crystal Parameters for $\alpha-\mathrm{Ga}_{0.2} \mathrm{Al}_{1.8} \mathrm{O}_{3}{ }^{a}$

\begin{tabular}{|c|c|c|c|c|c|c|}
\hline atom & Wyckoff site & $x$ & $y$ & $z$ & occupancy & $B_{\text {eq }}\left(\AA^{2}\right)$ \\
\hline Ga & $12 \mathrm{c}$ & 0 & 0 & $0.35289(8)$ & $0.09(6)$ & $0.22(5)$ \\
\hline $\mathrm{Al}$ & $12 c$ & 0 & 0 & $0.35289(8)$ & $0.91(6)$ & $0.22(5)$ \\
\hline $\mathrm{O}$ & $18 \mathrm{e}$ & $0.3057(3)$ & 0 & 0.25 & 1.0 & 0.22 \\
\hline
\end{tabular}

${ }^{a}$ Lattice parameters $a=4.78281(5) \AA, c=13.04096(15) \AA$, space group $R \overline{3} c H . R_{\mathrm{p}}=12.5 \% . w R_{\mathrm{p}}=19.0 \%$. GoF $=1.247$. The thermal parameter for oxygen was fixed to achieve a satisfactory fit.

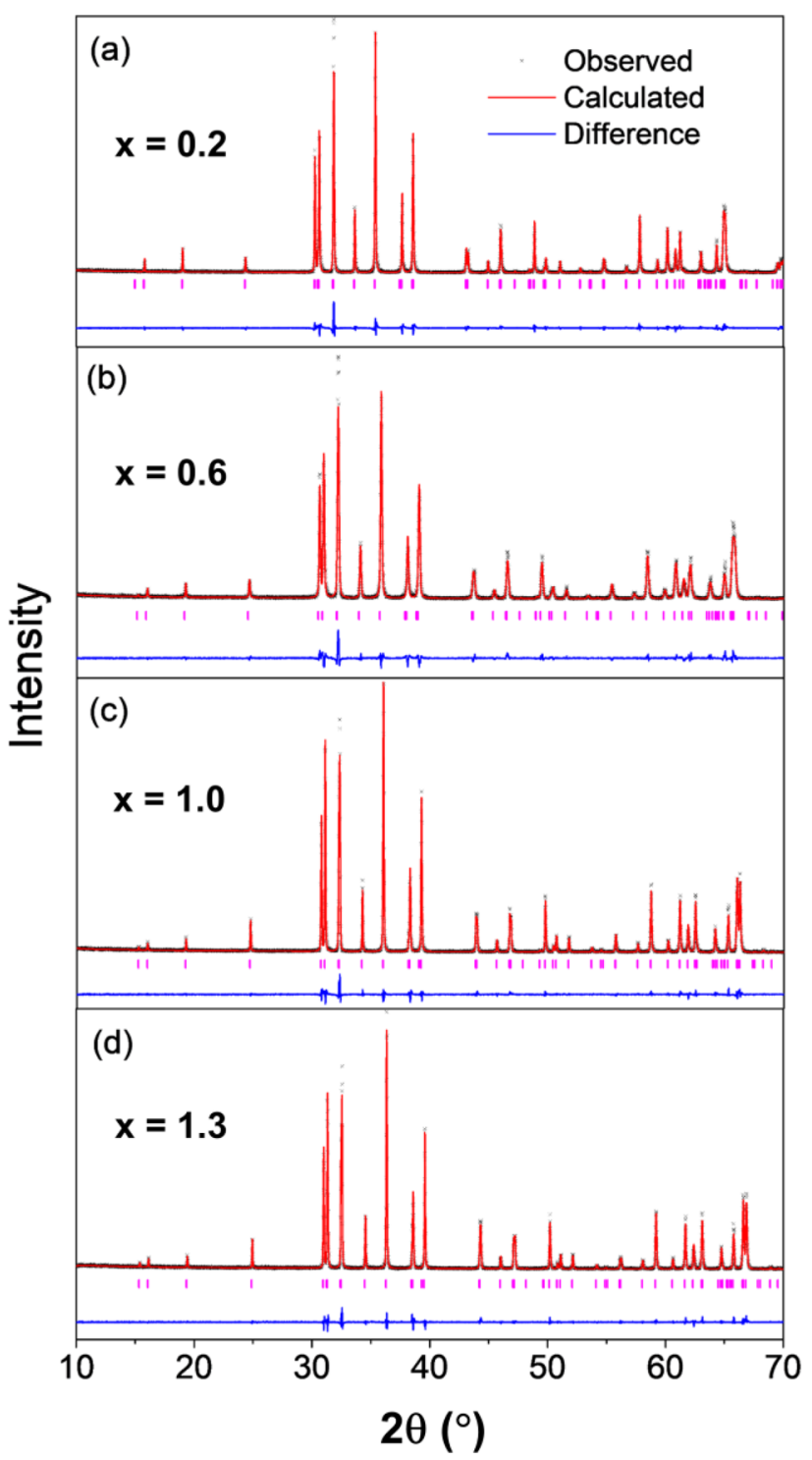

Figure 10. Rietveld refinement against powder XRD data $(\lambda=$ $1.54059 \AA$ ) for $\beta-\mathrm{Ga}_{2-x} \mathrm{Al}_{x} \mathrm{O}_{3}$ in the composition range of $0 \leq x \leq 1.3$.

and 1.6 and observed very similar behavior. From the integrated spectral intensities of the ${ }^{71} \mathrm{Ga}$ and ${ }^{27} \mathrm{Al} \mathrm{MAS}$ NMR spectra, it is possible to derive the bulk compositions for the $\gamma-\mathrm{Ga}_{2-x} \mathrm{Al}_{x} \mathrm{O}_{3}$ materials, shown in Table 3 .

In all five materials, the octahedral sites are almost fully occupied, meaning that the vacancies are located mainly on the tetrahedral sites. In the pure gallium oxide sample, the tetrahedral:octahedral ratio is $\sim 1: 2.7$, which is an occupancy of the octahedral sites substantially larger than that found in disordered $\gamma$-gallium oxide prepared from amorphous gels (1:2.1 ratio). ${ }^{16}$ These NMR and compositional data are also plotted graphically in Figure 8 to show how the changes in

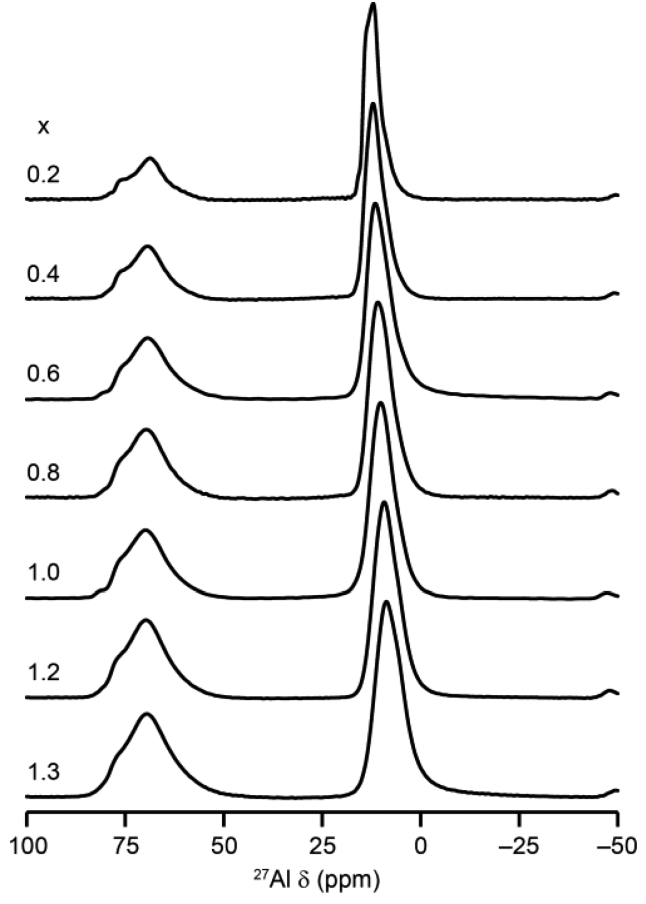

Figure 11. ${ }^{27} \mathrm{Al}(14.1 \mathrm{~T}, 20 \mathrm{kHz}$ MAS) NMR spectra of $\beta$ $\mathrm{Ga}_{2-x} \mathrm{Al}_{x} \mathrm{O}_{3}$. The minor resonance at $-50 \mathrm{ppm}$ in all spectra is a spinning side band.

relative octahedral:tetrahedral proportion and site occupancy depend upon the composition of the spinel. It should be noted that this is an oversimplification, however, because partial occupation of nonspinel sites may also be possible, as has been found in both the crystalline pure $\gamma-\mathrm{Al}_{2} \mathrm{O}_{3}$ and $\gamma-\mathrm{Ga}_{2} \mathrm{O}_{3}$ structures. ${ }^{15,16,20}$ These extra sites also have tetrahedral and octahedral coordination; however, the disordered nature of these materials causes broadening in the NMR spectra, and it was not possible to resolve additional signals for these sites. It has also been proposed that the occupancy of extra sites is greater in the poorly crystalline samples of $\gamma-\mathrm{Ga}_{2} \mathrm{O}_{3}{ }^{16}$ than in more crystalline samples, so it is likely that similar additional sites are occupied in these new materials. Additionally, it is known that $\gamma-\mathrm{Ga}_{2} \mathrm{O}_{3}$ exhibits a surface reconstruction that is enriched in octahedral sites, ${ }^{16}$ and ${ }^{1} \mathrm{H}-{ }^{27} \mathrm{Al}$ cross-polarization (CP) MAS NMR experiments (Figure S10) support a similar reconstruction here. The $\mathrm{CP}$ MAS experiment transfers magnetization from ${ }^{1} \mathrm{H}$ (which should be found mainly in surface $\mathrm{OH}$ species) to nearby ${ }^{27} \mathrm{Al}$ nuclei and is, therefore, effectively surface selective. However, it should be noted that, even in these surface-selective spectra, very little signal is observed for pentacoordinate $\mathrm{Al}$, which has previously been observed by NMR spectroscopy for $\gamma-\mathrm{Al}_{2} \mathrm{O}_{3}$ using surfaceselective dynamic nuclear polarization (DNP) measurements ${ }^{57-59}$ and has additionally been observed in MAS experiments by Areán et al. for $\gamma-\mathrm{Ga}_{2-x} \mathrm{Al}_{x} \mathrm{O}_{3}$ with $x=0.4$, 


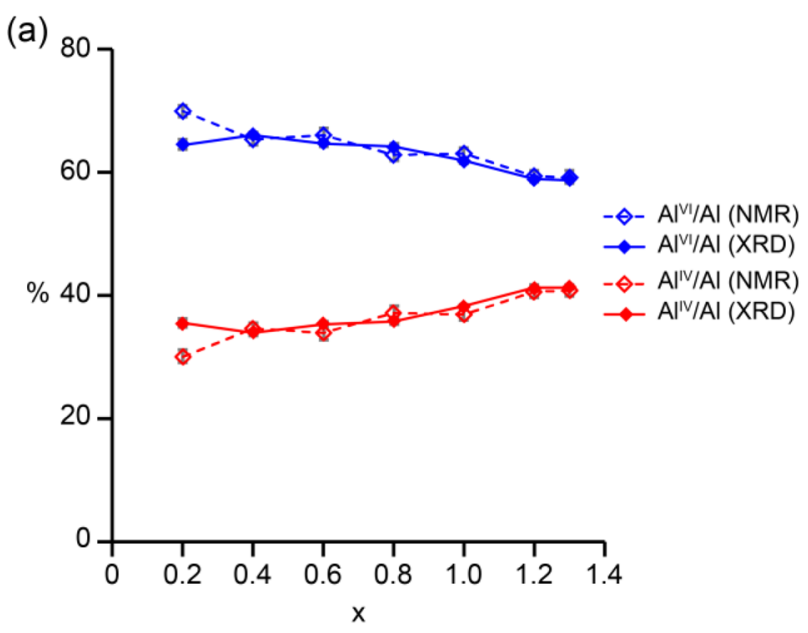

(b)

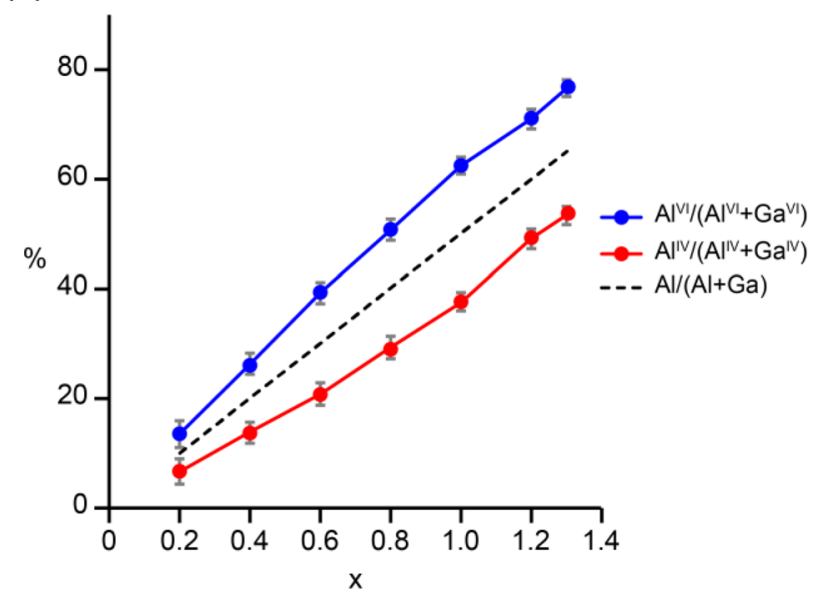

Figure 12. (a) Plot showing the proportion of tetrahedral (IV) and octahedral (VI) $\mathrm{Al}$ sites in $\beta-\mathrm{Ga}_{2-x} \mathrm{Al}_{x} \mathrm{O}_{3}$, as determined by Rietveld refinement (solid lines) and ${ }^{27} \mathrm{Al}$ NMR spectroscopy (dashed lines). (b) Plot showing the proportion of $\mathrm{Al}$ substitution on the tetrahedral and octahedral sites (solid lines) and the overall level of $\mathrm{Al}$ substitution in $\beta-\mathrm{Ga}_{2-x} \mathrm{Al}_{x} \mathrm{O}_{3}$ (dashed line). Note that the error bars in panel a are mainly smaller than the size of the points.

Table 5. Relative Occupation of Tetrahedral and Octahedral Sites in $\beta-\mathrm{Ga}_{2-x} \mathrm{Al}_{x} \mathrm{O}_{3}$ as Determined from the Average of the Values from Rietveld Refinement and ${ }^{27}$ Al MAS NMR Spectra and Overall Formulas Derived from Them

\begin{tabular}{|c|c|c|c|}
\hline$x$ & $\mathrm{Al}^{\mathrm{IV}}(\%)$ & $\mathrm{Al}^{\mathrm{VI}}(\%)$ & formula \\
\hline 0.0 & - & - & $\beta-\left(\mathrm{Ga}_{1.0}\right)^{\mathrm{tet}}\left[\mathrm{Ga}_{1.0}\right]^{\mathrm{cct} \mathrm{O}_{3}}$ \\
\hline 0.2 & 32.8 & 67.2 & $\beta-\left(\mathrm{Ga}_{0.934} \mathrm{Al}_{0.066}\right)^{\mathrm{tet}}\left[\mathrm{Ga}_{0.866} \mathrm{Al}_{0.134}\right]^{\mathrm{oct}} \mathrm{O}_{3}$ \\
\hline 0.4 & 34.3 & 65.7 & $\beta-\left(\mathrm{Ga}_{0.863} \mathrm{Al}_{0.137}\right)^{\text {tet }}\left[\mathrm{Ga}_{0.737} \mathrm{Al}_{0.263}\right]^{\text {oct }} \mathrm{O}_{3}$ \\
\hline 0.6 & 334.6 & 65.4 & $\beta-\left(\mathrm{Ga}_{0.792} \mathrm{Al}_{0.208}\right)^{\text {tet }}\left[\mathrm{Ga}_{0.608} \mathrm{Al}_{0.392}\right]^{\text {cct }} \mathrm{O}_{3}$ \\
\hline 0.8 & 36.6 & 63.4 & $\beta-\left(\mathrm{Ga}_{0.708} \mathrm{Al}_{0.292}\right)^{\mathrm{tet}}\left[\mathrm{Ga}_{0.492} \mathrm{Al}_{0.508}\right]^{\text {oct }} \mathrm{O}_{3}$ \\
\hline 1.0 & 37.6 & 62.4 & $\beta-\left(\mathrm{Ga}_{0.624} \mathrm{Al}_{0.376}\right)^{\mathrm{tet}}\left[\mathrm{Ga}_{0.376} \mathrm{Al}_{0.624}\right]^{\mathrm{oct}} \mathrm{O}_{3}$ \\
\hline 1.2 & 40.9 & 59.1 & $\beta-\left(\mathrm{Ga}_{0.509} \mathrm{Al}_{0.491}\right)^{\mathrm{tet}}\left[\mathrm{Ga}_{0.291} \mathrm{Al}_{0.709}\right]^{\text {oct }} \mathrm{O}_{3}$ \\
\hline 1.3 & 41.0 & 59.0 & $\beta-\left(\mathrm{Ga}_{0.466} \mathrm{Al}_{0.534}\right)^{\text {tet }}\left[\mathrm{Ga}_{0.234} \mathrm{Al}_{0.766}\right]^{\text {oct }} \mathrm{O}_{3}$ \\
\hline
\end{tabular}

1.0, and 1.6. ${ }^{56}$ It can, therefore, be concluded that the materials studied here have a surface that is enriched with octahedral $\mathrm{Al}$ relative to the bulk material.

$\boldsymbol{\beta}-\mathrm{Ga}_{2-x} \mathrm{Al}_{x} \mathrm{O}_{3}$ and $\boldsymbol{\alpha}-\mathrm{Ga}_{2-x} \mathrm{Al}_{x} \mathrm{O}_{3}$. The thermal decomposition of the $\mathrm{Ga}_{5-x} \mathrm{Al}_{x} \mathrm{O}_{7}(\mathrm{OH})$ materials is complex and, as for the pure aluminum ${ }^{60}$ and gallium ${ }^{15}$ end members, occurs via mixtures of poorly crystalline $\varepsilon$ - $(\mathrm{Al}, \mathrm{Ga})_{2} \mathrm{O}_{3}$ and $\kappa$ -
$(\mathrm{Al}, \mathrm{Ga})_{2} \mathrm{O}_{3}$, where it is difficult to determine if phase separation has taken place (Figures S4 and S5). Instead, we focus on the high-temperature phase transformation of the $\gamma$ $\mathrm{Ga}_{2-x} \mathrm{Al}_{x} \mathrm{O}_{3}$ spinels, because this occurs without phase separation. Substitution of aluminum for gallium in the spinel enhances the thermal stability of these phases over the pure gallium version (Figure S11): while pure nanocrystalline $\gamma$ $\mathrm{Ga}_{2} \mathrm{O}_{3}$ transforms directly into the thermodynamically stable polymorph, $\beta-\mathrm{Ga}_{2} \mathrm{O}_{3}$, at around $750{ }^{\circ} \mathrm{C}$, a higher temperature $\left(>900{ }^{\circ} \mathrm{C}\right)$ is required for the transformation of aluminumsubstituted samples. At $90 \% \mathrm{Al}$ substitution, the spinel converts directly into $\alpha-\mathrm{Ga}_{0.2} \mathrm{Al}_{1.8} \mathrm{O}_{3}$ without prior transformation into the $\beta$-polymorph. Rietveld analysis of a sample of $\alpha$ $\mathrm{Ga}_{0.2} \mathrm{Al}_{1.8} \mathrm{O}_{3}$ shows that the occupancy of the metal site for $\mathrm{Ga}$ and $\mathrm{Al}$ refines to 0.09 and 0.91 , respectively, in agreement with the nominal formula (Figure 9 and Table 4). ${ }^{27} \mathrm{Al}$ and ${ }^{71} \mathrm{Ga}$ MAS NMR spectra are consistent with the presence of only octahedral cations in this material (Figure S13).

Transformation of the mixed aluminum-gallium oxide spinels into phase-pure $\beta-\mathrm{Ga}_{2-x} \mathrm{Al}_{x} \mathrm{O}_{3}$ occurs for $\leq 65 \% \mathrm{Al}^{3+}$ substitution $(x=1.3)$, while the spinel phase separates into $\beta$ $\mathrm{Ga}_{2-x} \mathrm{Al}_{x} \mathrm{O}_{3}$ and $\alpha-\mathrm{Ga}_{2-x} \mathrm{Al}_{x} \mathrm{O}_{3}$ for $1.3<x<1.8$. Rietveld refinement against powder XRD data showed that no other crystalline phases were present in the $\beta-\mathrm{Ga}_{2-x} \mathrm{Al}_{x} \mathrm{O}_{3}$ samples (Figure 10). Two constraints were placed during the refinement. (i) The total occupancy of each site was fixed at 1.0 to maintain the charge balance against the oxide, and (ii) the total intended $\mathrm{Al}: \mathrm{Ga}$ ratio from the synthesis was fixed. Refinement statistics and refined crystal parameters for all samples can be found in Tables S7-S10. The change in the cell volume with an increase in aluminum content follows a linear relationship, obeying Vegard's law, and a decrease in the cell parameters with an increase in aluminum content is expected because of the smaller size of the $\mathrm{Al}^{3+}$ cation; an increase in the $\beta$ cell angle is also seen.

The structural refinements show that for all samples there is a significant amount of aluminum on the tetrahedral site, even for that with the lowest aluminum content. The $\mathrm{Al}^{(\mathrm{IV})}: \mathrm{Al}^{(\mathrm{VI})}$ ratio in the $\beta$-polymorph remains close to $1: 2$ across the composition range but shows a small increase (i.e., an increase in tetrahedral occupation) with an increase in $\mathrm{Al}$ substitution over values of $x$ between 0.2 and 1.3. While $\mathrm{Al}$ still displays a preference for octahedral coordination $\left[\right.$ the $\mathrm{Al}^{(\mathrm{IV})}: \mathrm{Al}^{(\mathrm{VI})}$ ratio in $\beta-\mathrm{Ga}_{2-x} \mathrm{Al}_{x} \mathrm{O}_{3}$ is $\left.1: 1\right]$, this preference is less pronounced than that observed above for $\mathrm{Ga}_{5-x} \mathrm{Al}_{x} \mathrm{O}_{7}(\mathrm{OH})$ and $\gamma-\mathrm{Ga}_{2-x} \mathrm{Al}_{x} \mathrm{O}_{3}$. This conclusion is also supported by DFT calculations, which suggest that substitution of $\mathrm{Al}$ onto a tetrahedral site in $\beta$ $\mathrm{Ga}_{2-x} \mathrm{Al}_{x} \mathrm{O}_{3}$ is less disfavored than in $\mathrm{Ga}_{5-x} \mathrm{Al}_{x} \mathrm{O}_{7} \mathrm{OH}$, with an energy penalty of $\sim 2.0 \mathrm{~kJ} / \mathrm{mol}$ of cations in $\beta-\mathrm{Ga}_{1.75} \mathrm{Al}_{0.25} \mathrm{O}_{3}$, compared with $\sim 5.2 \mathrm{~kJ} / \mathrm{mol}$ of cations for $\mathrm{Ga}_{4.5} \mathrm{Al}_{0.5} \mathrm{O}_{5} \mathrm{OH}$ (see the Supporting Information for details). ${ }^{27} \mathrm{Al}$ MAS NMR spectroscopy (Figure 11) confirms that $\mathrm{Al}$ adopts tetrahedral and octahedral coordination throughout the series, with the $\mathrm{Al}^{(\mathrm{IV})}: \mathrm{Al}^{(\mathrm{VI})}$ ratio varying systematically from $1: 2.25(\sim 31 \%$ tetrahedral Al) for $x=0.2$ to $1: 1.44(\sim 41 \%$ tetrahedral Al) for $x=1.3$.

As shown in Figure 12a, the relative site occupancies derived from the Rietveld refinements and ${ }^{27} \mathrm{Al} \mathrm{NMR}$ spectra are in good agreement for all compositions. Figure $12 \mathrm{~b}$ shows the fraction of octahedral and tetrahedral sites occupied by $\mathrm{Al}$ (from the average of the values obtained from the Rietveld refinements and ${ }^{27} \mathrm{Al}$ NMR spectra) for each composition, which confirms the slight preference for $\mathrm{Al}$ to occupy 
octahedral sites across the whole composition range. The average overall formulas derived from these data for all $\beta$ $\mathrm{Ga}_{2-x} \mathrm{Al}_{x} \mathrm{O}_{3}$ materials studied are listed in Table 5 .

There is very little difference in the refined crystal structure parameters between samples fired at 1200 and $1400{ }^{\circ} \mathrm{C}$ (Table $\mathrm{S} 11)$, implying that the $\mathrm{Al}$ adopts tetrahedral coordination immediately upon phase transformation from the mixed-metal spinels, rather than forming an initial $\beta$-polymorph with a smaller number of tetrahedral Al species, followed by rearrangement at a higher temperature.

As one would expect, the average $\mathrm{Al} / \mathrm{Ga}-\mathrm{O}$ interatomic distance becomes smaller with an increase in aluminum substitution in $\beta-\mathrm{Ga}_{2-x} \mathrm{Al}_{x} \mathrm{O}_{3}$ with a decrease in the average $\mathrm{Al}$ / $\mathrm{Ga}-\mathrm{O}$ tetrahedral distance from 1.816 to $1.789 \AA$ and $\mathrm{a}$ decrease in the average $\mathrm{Al} / \mathrm{Ga}-\mathrm{O}$ octahedral distance from 2.005 to $1.944 \AA$ from $x=0.2$ to $x=1.3$, respectively (see Table S12). Pure $\beta-\mathrm{Ga}_{2} \mathrm{O}_{3}$ shows a significant distortion of the octahedral sites away from regular octahedral geometry, ${ }^{17}$ which is also present in all $\beta-\mathrm{Ga}_{2-x} \mathrm{Al}_{x} \mathrm{O}_{3}$ samples in this work. The tetrahedral sites also appear to be significantly distorted for all samples, with the $\mathrm{O}-\mathrm{Ga} / \mathrm{Al}-\mathrm{O}$ angles falling in the range of $104-120^{\circ}$, a feature also observed in the single-crystal reinvestigation of $\beta-\mathrm{Ga}_{2} \mathrm{O}_{3}$ by $\AA$ hman et al. ${ }^{17}$ The ${ }^{27} \mathrm{Al}$ NMR spectra of $\beta-\mathrm{Ga}_{2-x} \mathrm{Al}_{x} \mathrm{O}_{3}$ (Figure 11) confirm that there is a large EFG at the tetrahedral site, leading to $C_{\mathrm{Q}}$ vales of $\sim 5.0$ $\mathrm{MHz}$ (and a similarly large $C_{\mathrm{Q}}$ of $\sim 11 \mathrm{MHz}$ is observed for $\beta$ $\left.\mathrm{Ga}_{2} \mathrm{O}_{3}{ }^{16}\right)$.

\section{CONCLUSIONS}

Solvothermal synthesis allows the formation of mixed aluminum-gallium oxides and oxyhydroxides using temperatures lower than those previously reported. The new solid solution $\mathrm{Ga}_{5-x} \mathrm{Al}_{x} \mathrm{O}_{7}(\mathrm{OH})(0.5 \leq x \leq 1.5)$ has been structurally authenticated, and the "hexagonal $\mathrm{GaAlO}_{3}$ " reported in the literature is a likely member of this family. The $\gamma-\mathrm{Ga}_{2-x} \mathrm{Al}_{x} \mathrm{O}_{3}$ spinels form as poorly crystalline powders that can be thermally transformed into the high-temperature phases $\beta-\mathrm{Ga}_{2-x} \mathrm{Al}_{x} \mathrm{O}_{3}(0 \leq x \leq 1.3)$ and $\alpha-\mathrm{Ga}_{2-x} \mathrm{Al}_{x} \mathrm{O}_{3}(x=$ 1.8). This provides highly crystalline samples for which a detailed solid-state NMR spectroscopic investigation allows the distribution of site occupancies to be determined. Given the growing interest in gallium oxide polymorphs in applications such as electronics and photocatalysis, and the long-standing study of aluminum oxides as catalyst supports in heterogeneous catalysis, our results will provide reference data for understanding structure-property relationships in these fields.

\section{ASSOCIATED CONTENT}

\section{SI Supporting Information}

The Supporting Information is available free of charge at https://pubs.acs.org/doi/10.1021/acs.inorgchem.9b03459.

Additional experimental data for $\mathrm{Ga}_{5-x} \mathrm{Al}_{x} \mathrm{O}_{7}(\mathrm{OH})$, further details of DFT calculations, and additional experimental data for $\gamma-\mathrm{Ga}_{2-x} \mathrm{Al}_{x} \mathrm{O}_{3}, \alpha-\mathrm{Ga}_{2-x} \mathrm{Al}_{x} \mathrm{O}_{3}$, and $\beta-\mathrm{Ga}_{2-x} \mathrm{Al}_{x} \mathrm{O}_{3}$ (PDF)

\section{AUTHOR INFORMATION}

\section{Corresponding Authors}

Sharon E. Ashbrook - School of Chemistry, EaStCHEM and Centre of Magnetic Resonance, University of St Andrews, St Andrews KY16 9ST, U.K.; 이이.org/0000-0002-45386782; Email: sema@st-andrews.ac.uk
Richard I. Walton - Department of Chemistry, University of Warwick, Coventry CV4 7AL, U.K.; (1) orcid.org/0000-00019706-2774; Email: r.i.walton@warwick.ac.uk

\section{Authors}

Daniel S. Cook - Department of Chemistry, University of Warwick, Coventry CV4 7AL, U.K.

Joseph E. Hooper - School of Chemistry, EaStCHEM and Centre of Magnetic Resonance, University of St Andrews, St Andrews KY16 9ST, U.K.

Daniel M. Dawson - School of Chemistry, EaStCHEM and Centre of Magnetic Resonance, University of St Andrews, St Andrews KY16 9ST, U.K.; (1) orcid.org/0000-0002-81104535

Janet M. Fisher - Johnson Matthey Technology Centre, Reading RG4 9NH, U.K.

David Thompsett - Johnson Matthey Technology Centre, Reading RG4 9NH, U.K.

Complete contact information is available at:

https://pubs.acs.org/10.1021/acs.inorgchem.9b03459

\section{Notes}

The authors declare no competing financial interest.

\section{ACKNOWLEDGMENTS}

D.S.C. is grateful to the EPSRC for the award of an industrial CASE studentship, partly funded by Johnson Matthey plc. S.E.A., D.M.D., and J.E.H. thank the ERC (EU FP7 Consolidator Grant 614290 "EXONMR") for funding. S.E.A. thanks the Royal Society and Wolfson Foundation for a merit award. The UK $850 \mathrm{MHz}$ solid-state NMR Facility used in this research was funded by EPSRC and BBSRC (Contract Reference PR140003), as well as the University of Warwick, including via partial funding through Birmingham Science City Advanced Materials Projects 1 and 2 supported by Advantage West Midlands (AWM) and the European Regional Development Fund (ERDF). Collaborative assistance from the 850 $\mathrm{MHz}$ Facility Manager (Dinu Iuga, University of Warwick) is acknowledged. EPSRC is also thanked for computational support through the Collaborative Computational Project on NMR Crystallography (CCP-NC), via EP/M022501/1 and $\mathrm{EP} / \mathrm{J} 501542 / 1$. The research data (and/or materials) supporting this publication can be accessed at http://doi.org/ $10.17630 / 3$ cea1660-1368-442d-a012-d63e16e2a7c3. ${ }^{61}$

\section{REFERENCES}

(1) Levin, I.; Brandon, D. Metastable alumina polymorphs: Crystal structures and transition sequences. J. Am. Ceram. Soc. 1998, 81, 1995-2012.

(2) Trueba, M.; Trasatti, S. P. $\gamma$-Alumina as a support for catalysts: A review of fundamental aspects. Eur. J. Inorg. Chem. 2005, 2005, 33933403.

(3) K. Wefers, C. M. Oxides and Hydroxides of Aluminum; ALCOA Laboratories: Pittsburgh, PA, 1987; p 20.

(4) Stepanov, S. I.; Nikolaev, V. I.; Bougrov, V. E.; Romanov, A. E. Gallium Oxide: Properties and Applications - A Review. Rev. Adv. Mater. Sci. 2016, 44, 63-86.

(5) Higashiwaki, M.; Jessen, G. H. Guest Editorial: The dawn of gallium oxide microelectronics. Appl. Phys. Lett. 2018, 112, 060401.

(6) Wang, X.; Xu, Q.; Li, M. R.; Shen, S.; Wang, X. L.; Wang, Y. C.; Feng, Z. C.; Shi, J. Y.; Han, H. X.; Li, C. Photocatalytic Overall Water Splitting Promoted by an $\alpha-\beta$ phase Junction on $\mathrm{Ga}_{2} \mathrm{O}_{3}$. Angew. Chem., Int. Ed. 2012, 51, 13089-13092. 
(7) Jin, S. Q.; Wang, X.; Wang, X. L.; Ju, M. G.; Shen, S.; Liang, W. Z.; Zhao, Y.; Feng, Z. C.; Playford, H. Y.; Walton, R. I.; Li, C. Effect of Phase Junction Structure on the Photocatalytic Performance in Overall Water Splitting: $\mathrm{Ga}_{2} \mathrm{O}_{3}$ Photocatalyst as an Example. J. Phys. Chem. C 2015, 119, 18221-18228.

(8) Roy, R.; Hill, V. G.; Osborn, E. F. Polymorphism of $\mathrm{Ga}_{2} \mathrm{O}_{3}$ and the System $\mathrm{Ga}_{2} \mathrm{O}_{3}-\mathrm{H}_{2} \mathrm{O}$. J. Am. Chem. Soc. 1952, 74, 719-722.

(9) Roy, R.; Hill, V. G.; Osborn, E. F. Polymorphs of Alumina and Gallia. Ind. Eng. Chem. 1953, 45, 819-820.

(10) Lavalley, J. C.; Daturi, M.; Montouillout, V.; Clet, G.; Otero Areán, C.; Rodríguez Delgado, M.; Sahibed-dine, A. Unexpected similarities between the surface chemistry of cubic and hexagonal gallia polymorphs. Phys. Chem. Chem. Phys. 2003, 5, 1301-1305.

(11) Rodríguez Delgado, M.; Otero Areán, C. Surface chemistry and pore structure of $\beta-\mathrm{Ga}_{2} \mathrm{O}_{3}$. Mater. Lett. 2003, 57, 2292-2297.

(12) Yoshioka, S.; Hayashi, H.; Kuwabara, A.; Oba, F.; Matsunaga, K.; Tanaka, I. Structures and energetics of $\mathrm{Ga}_{2} \mathrm{O}_{3}$ polymorphs. J. Phys.: Condens. Matter 2007, 19, 346211.

(13) Penner, S.; Zhuo, C.; Thalinger, R.; Grunbacher, M.; Hejny, C.; Vanicek, S.; Noisternig, M. Physico-chemical properties of unusual $\mathrm{Ga}_{2} \mathrm{O}_{3}$ polymorphs. Monatsh. Chem. 2016, 147, 289-300.

(14) Shi, L. H.; Zhang, J.; Wu, S.; Li, Y. G.; Jiang, L. N.; Cui, Q. L. Phase Evolution of $\mathrm{Ga}_{2} \mathrm{O}_{3}$ Produced from Morphology-Controllable alpha-GaOOH Nanocrystals. J. Am. Ceram. Soc. 2014, 97, 26072614.

(15) Playford, H. Y.; Hannon, A. C.; Barney, E. R.; Walton, R. I. Structures of Uncharacterised Polymorphs of Gallium Oxide from Total Neutron Diffraction. Chem. - Eur. J. 2013, 19, 2803-2813.

(16) Playford, H. Y.; Hannon, A. C.; Tucker, M. G.; Dawson, D. M.; Ashbrook, S. E.; Kastiban, R. J.; Sloan, J.; Walton, R. I. Characterization of Structural Disorder in $\gamma-\mathrm{Ga}_{2} \mathrm{O}_{3}$. J. Phys. Chem. C 2014, 118, $16188-16198$.

(17) Åhman, J.; Svensson, G.; Albertsson, J. A reinvestigation of $\beta$ gallium oxide. Acta Crystallogr., Sect. C: Cryst. Struct. Commun. 1996, $52,1336-1338$

(18) Wang, H.; He, Y.; Chen, W.; Zeng, Y. W.; Stahl, K.; Kikegawa, T.; Jiang, J. Z. High-pressure behavior of $\beta-\mathrm{Ga}_{2} \mathrm{O}_{3}$ nanocrystals. J. Appl. Phys. 2010, 107, 033520.

(19) Kim, S. W.; Iwamoto, S.; Inoue, M. Solvothermal oxidation of gallium metal. Ceram. Int. 2009, 35, 1603-1609.

(20) Smrčok, L.; Langer, V.; Křestan, J. $\gamma$-Alumina: a single-crystal Xray diffraction study. Acta Crystallogr., Sect. C: Cryst. Struct. Commun. 2006, 62, I83-I84.

(21) Hill, V. G.; Roy, R.; Osborn, E. F. The System Alumina-GalliaWater. J. Am. Ceram. Soc. 1952, 35, 135-142.

(22) von Wartenerg, H.; Reusch, H. J. Schmelzdiagramme höchstfeuerfester Oxyde. IV. (Aluminiumoxyd)Oxyde. IV. (Aluminiumoxyd). Z. Anorg. Allg. Chem. 1932, 207, 1-20.

(23) Macdonald, J.; Gard, J.; Glasser, F. Preparation and crystal chemistry of some mixed metal sesquioxides containing $\mathrm{Fe}, \mathrm{Al}, \mathrm{Ga}, \mathrm{Cr}$, Sc and In. J. Inorg. Nucl. Chem. 1967, 29, 661-671.

(24) Takahashi, M.; Inoue, N.; Takeguchi, T.; Iwamoto, S.; Inoue, M.; Watanabe, T. Synthesis of $\gamma-\mathrm{Ga}_{2} \mathrm{O}_{3}-\mathrm{Al}_{2} \mathrm{O}_{3}$ solid solutions by the glycothermal method. J. Am. Ceram. Soc. 2006, 89, 2158-2166.

(25) Takahashi, M.; Nakatani, T.; Iwamoto, S.; Watanabe, T.; Inoue, M. Performance of solvothermally prepared $\mathrm{Ga}_{2} \mathrm{O}_{3}-\mathrm{Al}_{2} \mathrm{O}_{3}$ catalysts for SCR of NO with methane. Appl. Catal., B 2007, 70, 73-79.

(26) Masuda, T.; Watanabe, T.; Miyahara, Y.; Kanai, H.; Inoue, M. Synthesis of $\mathrm{Ga}_{2} \mathrm{O}_{3}-\mathrm{Al}_{2} \mathrm{O}_{3}$ Catalysts by a Coprecipitation Method for $\mathrm{CH}_{4}$-SCR of NO. Top. Catal. 2009, 52, 699-706.

(27) Nakatani, T.; Watanabe, T.; Takahashi, M.; Miyahara, Y.; Deguchi, H.; Iwamoto, S.; Kanai, H.; Inoue, M. Characterization of $\gamma$ $\mathrm{Ga}_{2} \mathrm{O}_{3}-\mathrm{Al}_{2} \mathrm{O}_{3}$ Prepared by Solvothermal Method and Its Performance for Methane-SCR of NO. J. Phys. Chem. A 2009, 113, 7021-7029.

(28) Masuda, T.; Watanabe, T.; Miyahara, Y.; Iwamoto, S.; Kanai, $\mathrm{H}$.; Inoue, M. Photoluminescence of propylene adsorbed on $\gamma-\mathrm{Ga}_{2} \mathrm{O}_{3}$ $\mathrm{Al}_{2} \mathrm{O}_{3}$ solid solutions in relation to their catalysis for $\mathrm{CH}_{4}-\mathrm{SCR}$ of $\mathrm{NO}$. J. Mol. Catal. A: Chem. 2009, 307, 71-76.
(29) Takahashi, M.; Inoue, N.; Nakatani, T.; Takeguchi, T.; Iwamoto, S.; Watanabe, T.; Inoue, M. Selective catalytic reduction of $\mathrm{NO}$ with methane on $\gamma-\mathrm{Ga}_{2} \mathrm{O}_{3}-\mathrm{Al}_{2} \mathrm{O}_{3}$ solid solutions prepared by the glycothermal method. Appl. Catal., B 2006, 65, 142-149.

(30) Miyahara, Y.; Takahashi, M.; Masuda, T.; Imamura, S.; Kanai, H.; Iwamoto, S.; Watanabe, T.; Inoue, M. Selective catalytic reduction of NO with C1-C3 reductants over solvothermally prepared $\mathrm{Ga}_{2} \mathrm{O}_{3}$ $\mathrm{Al}_{2} \mathrm{O}_{3}$ catalysts: Effects of water vapor and hydrocarbon uptake. Appl. Catal., B 2008, 84, 289-296.

(31) Miyahara, Y.; Watanabe, T.; Masuda, T.; Kanai, H.; Deguchi, $\mathrm{H}$.; Inoue, $\mathrm{M}$. Evaluation of catalytic activity of $\mathrm{Ga}_{2} \mathrm{O}_{3}-\mathrm{Al}_{2} \mathrm{O}_{3}$ solid solutions for $\mathrm{CH}_{4}$-SCR by UV-vis spectra after adsorption of $\mathrm{C}_{3} \mathrm{H}_{6}$ as a probe. J. Catal. 2008, 259, 36-42.

(32) Chen, M.; Xu, J.; Su, F. Z.; Liu, Y. M.; Cao, Y.; He, H. Y.; Fan, K. N. Dehydrogenation of propane over spinel-type gallia-alumina solid solution catalysts. J. Catal. 2008, 256, 293-300.

(33) Xiao, H.; Zhang, J. F.; Wang, P.; Wang, X. X.; Pang, F.; Zhang, Z. Z.; Tan, Y. S. Dehydrogenation of propane over a hydrothermalsynthesized $\mathrm{Ga}_{2} \mathrm{O}_{3}-\mathrm{Al}_{2} \mathrm{O}_{3}$ catalyst in the presence of carbon dioxide. Catal. Sci. Technol. 2016, 6, 5183-5195.

(34) Mathew, T.; Yamada, Y.; Ueda, A.; Shioyama, H.; Kobayashi, T. Metal oxide catalysts for DME steam reforming: $\mathrm{Ga}_{2} \mathrm{O}_{3}$ and $\mathrm{Ga}_{2} \mathrm{O}_{3}-\mathrm{Al}_{2} \mathrm{O}_{3}$ catalysts with and without copper. Appl. Catal., A 2005, $286,11-22$.

(35) Akatsuka, M.; Yoshida, T.; Yamamoto, N.; Yamamoto, M.; Ogawa, S.; Yagi, S. XAFS analysis for quantification of the gallium coordinations in $\mathrm{Al}_{2} \mathrm{O}_{3}$-supported $\mathrm{Ga}_{2} \mathrm{O}_{3}$ photocatalysts. J. Phys.: Conf. Ser. 2016, 712, No. 012056.

(36) Coelho, A. A. TOPAS and TOPAS-Academic: an optimization program integrating computer algebra and crystallographic objects written in C plus. J. Appl. Crystallogr. 2018, 51, 210-218.

(37) Amoureux, J. P.; Fernandez, C.; Steuernagel, S. Z filtering in MQMAS NMR. J. Magn. Reson., Ser. A 1996, 123, 116-118.

(38) Pike, K. J.; Malde, R. P.; Ashbrook, S. E.; McManus, J.; Wimperis, S. Multiple-quantum MAS NMR of quadrupolar nuclei. Do five-, seven- and nine-quantum experiments yield higher resolution than the three-quantum experiment? Solid State Nucl. Magn. Reson. 2000, 16, 203-215.

(39) Clark, S. J.; Segall, M. D.; Pickard, C. J.; Hasnip, P. J.; Probert, M. J.; Refson, K.; Payne, M. C. First principles methods using CASTEP. Z. Kristallogr. - Cryst. Mater. 2005, 220, 567-570.

(40) Pickard, C. J.; Mauri, F. All-electron magnetic response with pseudopotentials: NMR chemical shifts. Phys. Rev. B: Condens. Matter Mater. Phys. 2001, 63, 245101.

(41) Perdew, J. P.; Burke, K.; Ernzerhof, M. Generalized gradient approximation made simple. Phys. Rev. Lett. 1996, 77, 3865-3868.

(42) Tkatchenko, A.; Scheffler, M. Accurate Molecular Van Der Waals Interactions from Ground-State Electron Density and FreeAtom Reference Data. Phys. Rev. Lett. 2009, 102, No. 073005.

(43) McNellis, E. R.; Meyer, J.; Reuter, K. Azobenzene at coinage metal surfaces: Role of dispersive van der Waals interactions. Phys. Rev. B: Condens. Matter Mater. Phys. 2009, 80, 205414.

(44) Monkhorst, H. J.; Pack, J. D. Special Points For Brillouin-Zone Integrations. Phys. Rev. B 1976, 13, 5188-5192.

(45) Pyykko, P. Year-2017 nuclear quadrupole moments. Mol. Phys. 2018, 116, 1328-1338.

(46) Stephens, P. W. Phenomenological model of anisotropic peak broadening in powder diffraction. J. Appl. Crystallogr. 1999, 32, 281289.

(47) Demichelis, R.; Noel, Y.; Zicovich-Wilson, C. M.; Roetti, C.; Valenzano, L.; Dovesi, R. Ab-initio quantum mechanical study of akdalaite $\left(5 \mathrm{Al}_{2} \mathrm{O}_{3} \cdot \mathrm{H}_{2} \mathrm{O}\right)$ : Structure and vibrational spectrum. J. Phys.: Conf. Ser. 2008, 117, No. 012013.

(48) Yamaguchi, G.; Yanagida, H.; Ono, S. The Crystal Structure of Tohdite. Bull. Chem. Soc. Jpn. 1964, 37, 1555-1557.

(49) Shpanov, Y. P.; Sidorenko, G. A.; Stolyarova, T. I. Akdalaite, a new hydrated variety of alumina. Int. Geol. Rev. 1971, 13, 675-680.

(50) Yamaguchi, G.; Yanagida, H.; Ono, S. A New Alumina Hydrate, "Tohdite" $\left(5 \mathrm{Al}_{2} \mathrm{O}_{3} \cdot \mathrm{H}_{2} \mathrm{O}\right)$. Bull. Chem. Soc. Jpn. 1964, 37, 752-754. 
(51) Hwang, S.-L.; Shen, P.; Chu, H.-T.; Yui, T.-F. A New Occurrence and New Data on Akdalaite, a Retrograde Mineral from UHP Whiteschist, Kokchetav Massif, Northern Kazakhstan. Int. Geol. Rev. 2006, 48, 754-764.

(52) MacKenzie, K. J. D.; Smith, M. E. Multinuclear Solid-State NMR of Inorganic Materials; Pergamon Press: Oxford, U.K., 2002.

(53) Ashbrook, S. E.; Sneddon, S. New Methods and Applications in Solid-State NMR Spectroscopy of Quadrupolar Nuclei. J. Am. Chem. Soc. 2014, 136, 15440-15456.

(54) Moran, R. F.; Dawson, D. M.; Ashbrook, S. E. Exploiting NMR spectroscopy for the study of disorder in solids. Int. Rev. Phys. Chem. 2017, 36, 39-115.

(55) Gutierrez, G.; Taga, A.; Johansson, B. Theoretical structure determination of $\gamma-\mathrm{Al}_{2} \mathrm{O}_{3}$. Phys. Rev. B: Condens. Matter Mater. Phys. 2001, 65, 012101.

(56) Areán, C. O.; Delgado, M. R.; Montouillout, V.; Massiot, D. Synthesis and characterization of spinel-type gallia-alumina solid solutions. Z. Anorg. Allg. Chem. 2005, 631, 2121-2126.

(57) Lee, D.; Duong, N. T.; Lafon, O.; De Paepe, G. Primostrato Solid-State NMR Enhanced by Dynamic Nuclear Polarization: Pentacoordinated $\mathrm{Al}^{3+}$ Ions Are Only Located at the Surface of Hydrated $\gamma$-Alumina. J. Phys. Chem. C 2014, 118, 25065-25076.

(58) Rankin, A. G. M.; Webb, P. B.; Dawson, D. M.; Viger-Gravel, J.; Walder, B. J.; Emsley, L.; Ashbrook, S. E. Determining the Surface Structure of Silicated Alumina Catalysts via Isotopic Enrichment and Dynamic Nuclear Polarization Surface-Enhanced NMR Spectroscopy. J. Phys. Chem. C 2017, 121, 22977-22984.

(59) Mais, M.; Paul, S.; Barrow, N. S.; Titman, J. J. Dynamic Nuclear Polarisation Enhanced Solid-State Nuclear Magnetic Resonance Studies of Surface Modification of $\gamma$-Alumina. Johnson Matthey Technol. Rev. 2018, 62, 271-278.

(60) Okumiya, M.; Yamaguchi, G.; Yamada, O.; Ono, S. The Formation of $\kappa$ and $\kappa^{\prime}-\mathrm{Al}_{2} \mathrm{O}_{3}$ from the Dehydration of Tohdite $5 \mathrm{Al}_{2} \mathrm{O}_{3} \cdot \mathrm{H}_{2} \mathrm{O}$. Bull. Chem. Soc. Jpn. 1971, 44, 418-423.

(61) Cook, D. S.; Hooper, J. E.; Dawson, D. M.; Fisher, J. M.; Thompsett, D.; Ashbrook, S. E.; Walton, R. I. Synthesis and Polymorphism of Mixed Aluminum-Gallium Oxides. Dataset. University of St Andrews Research Portal, 2019. 